Review

\title{
Between the Unstoppable and the Feasible: The Lucid Pragmatism of Transition Processes for Sustainable Urban Mobility: A Literature Review
}

\author{
Filipa Corais ${ }^{1,2, *}$, Miguel Bandeira ${ }^{3}$, Cecília Silva ${ }^{4}(\mathbb{D})$ and Luís Bragança ${ }^{5}$
}

check for

updates

Citation: Corais, F.; Bandeira, M.;

Silva, C.; Bragança, L. Between the Unstoppable and the Feasible: The Lucid Pragmatism of Transition Processes for Sustainable Urban Mobility: A Literature Review. Future Transp. 2022, 2, 86-114. https:// doi.org/10.3390/futuretransp2010006

Academic Editor: Gabriella Mazzulla

Received: 2 November 2021

Accepted: 7 January 2022

Published: 29 January 2022

Publisher's Note: MDPI stays neutral with regard to jurisdictional claims in published maps and institutional affiliations.

Copyright: (c) 2022 by the authors. Licensee MDPI, Basel, Switzerland. This article is an open access article distributed under the terms and conditions of the Creative Commons Attribution (CC BY) license (https:// creativecommons.org/licenses/by/ $4.0 /)$.
1 Heritage and Territory Laboratory (Lab2PT), School of Architecture Arte and Design, University of Minho, 4800-058 Guimarães, Portugal

2 Department of Mobility, Municipality of Braga, 4704-514 Braga, Portugal

3 CECS-Communication and Society Research Centre, Social Sciences Institute, University of Minho, 4710-057 Braga, Portugal; bandeira@ics.uminho.pt

4 CITTA-Research Centre for Territory, Transports and Environment, Faculty of Engineering, University of Porto, 4200-465 Porto, Portugal; ccsilva@fe.up.pt

5 Civil Engineering Department, University of Minho, 4800-058 Guimarães, Portugal; braganca@civil.uminho.pt

* Correspondence: fcorais@gmail.com

\begin{abstract}
This article presents a literature review of Transition Experiments applied to the Sustainable Urban Mobility context from a critical and operative point of view. The moment of transformation that we are living through determines concerns about the decarbonization and compliance with the 2050 Targets and imposes a paradigm shift towards sustainable urban mobility. In this regard, the necessary physical change will have to be accompanied by a socio-cultural transition, of which the challenge implies the construction of a collective ideal, shared by the population and the main stakeholders, leading to the opening of new political spaces and a change, also in terms of governance.
\end{abstract}

Keywords: Transition Experiments; sustainable urban mobility; living lab; urban design

\section{Introduction}

The concept of Transition Experiments (TE) is quite recent (it emerged at the end of the 20th century) and is intrinsically associated with sustainable development.

The last decade has seen an enormous evolution of research on TE for sustainability, but at the level of specific application of these theories towards Sustainable Urban Mobility (SUM) [1-14], there is still a long way to go, so it is pertinent to review the current state of the situation in this regard.

Thus, the aim of this article, which adheres to the precepts of a systematic literature review, is pursued by the following research question:

How do the transition experiences apply and how can they contribute to the promotion of Sustainable Urban Mobility?

The global awareness of climate change, namely, the effects arising from the rise in temperature and the relevance of its relationship with decarbonization [15], is necessary regardless of the commitments made for 2050 [16]. To ensure their efficiency, Banister [17] considers that strategies to promote Sustainable Urban Mobility will have to be framed in packages of "push \& pull" and "hard \& soft" measures, thus not neglecting the participatory process and involvement of society in the urban design and options that frame a transversality of scales before the decision making [16].

Yet how do we deal with the low level of public and (local) political acceptance for the transition to SUM?

Banister [18] considers that the key to behavioral change lies in engaging all stakeholders in a proper understanding of the fundamentals that underlie the political-ideological change. In this sense, he considers that a strong local leadership and governance structure 
is fundamental to ensure that immediate Mobility actions are being guided by a long-term vision based on a sense of responsibility for global commitments [16].

This understanding is in line with the spirit and overall vision of the present article, which focuses on the methodology of TE applied to the promotion of SUM.

To reach the answer to the research question, the article is structured as follows:

Section 2 explains the methodology developed (based on the PRISMA guidelines) to synthesize and review the existing literature on the topic in question.

Section 3 discusses the evolution of the TE concept and details the diversity of (sub)concepts, the main characteristics of TE, TE types, and the process of the transition cycle.

Section 4 highlights the importance of public participation in TE processes.

Section 5 reflects on the implications of TE on the urban design of public space.

Section 6 considers the effects that TE interventions have on the promotion of SUM in relation to changes in the culture of mobility and urban living.

Section 7 provides a critical reflection based on a compilation of different approaches by various TE researchers [4,19-22].

Finally, Section 8 outlines the main conclusions on the specific features of TE applied to the promotion of SUM (in contrast to traditional planning and incremental policies) and future directions.

\section{Methodology of the Literature Review Approach}

For the completion of this article, a systematic review of the literature was applied, resorting to an analysis of highly cited articles on Transition Experiments in a comprehensive coverage, followed by the corresponding overview of the results obtained ([12] p. 154).

The selection of the bibliographic references was based on reliable and recent literature review publications, such as Sengers et al. [12], Schussel [11], Bertolini [3], Avelino [23], and Bruine et al. [4]. Research was also used by reputable authors in the topics to be addressed (e.g., Avelino, Bertolini, Foxon, Frantzeskaki, Geels, Loorbach, Nevens, Porter, Roorda, Rotmans, Sengers, Van den Bosch), by keywords (e.g., urban transition, transition experiment, sustainability transition, governance experimentation, social learning), and by theme (Transition Experiments and Sustainable Urban Mobility) in databases such as Scopus, ResearchGate, Google Scholar, or Academia.edu, among others, and in lists of the Sustainability Transitions Research Network (STRN).

The search was restricted to publications of documents dedicated to the approach of Transition Experiments and sustainable urban mobility, which generated the compilation of about 118 publications (e.g., articles, conference papers, books, chapters, theses). The selected publications (in the Appendix A) focus mainly on documents published from 2010 onwards (Figure 1).

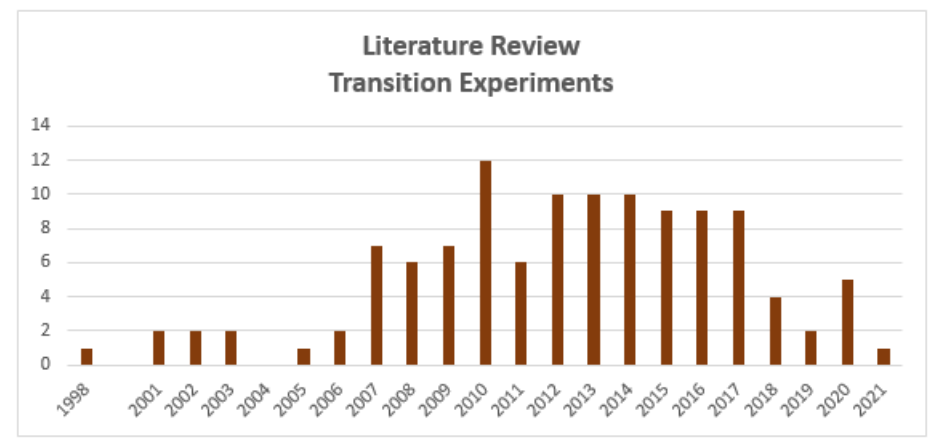

Figure 1. Year of publication of the 118 documents selected in the literature review of TE.

These publications were systematized using an Excel file, which revealed the main data of each publication (e.g., year and type of publication, abstract, conclusions, observations, main bibliographical references, the relevance of the publication for the present research) and categorized each publication into five typologies of research approach (simultaneous or 
not): literature review, conceptual, methodological, case studies (mainly in the Netherlands, but also in the United Kingdom, Belgium, Germany, Austria, and Sweden), and critical view. This organization allowed us to identify and select the main publications to be considered for this article (Table 1).

Table 1. Types of research approach of the main publications of TE considered.

\begin{tabular}{|c|c|c|c|c|c|}
\hline \multirow{2}{*}{ References of Transition Experiments } & \multicolumn{5}{|c|}{ Typology of Approach } \\
\hline & Literature Review & Case Study & Conceptual & Methodological & Critical \\
\hline $\begin{array}{c}\text { Avelino, F. (2011, December 9). Power in Transition: } \\
\text { Empowering Discourses on Sustainability Transitions. } \\
\text { Erasmus University Rotterdam. Retrieved from } \\
\text { http:/ /hdl.handle.net/1765/30663 (accessed on } 12 \\
\text { June 2021) }\end{array}$ & $\bullet$ & $\bullet$ & $\bullet$ & & \\
\hline $\begin{array}{l}\text { Avelino, F. \& Rotmans, J. (2009). Power in Transition: } \\
\text { An Interdisciplinary Framework to Study Power in } \\
\text { Relation to Structural Change. European Journal of } \\
\text { Social Theory, 12(4), 543-569. } \\
\text { doi:10.1177/1368431009349830***** }\end{array}$ & & & $\bullet$ & & \\
\hline $\begin{array}{l}\text { Bertolini, L. (2020). From "streets for traffic" to "streets } \\
\text { for people": can street experiments transform urban } \\
\text { mobility?. Transport Reviews, 40(6), 734-753. } \\
\text { https:/ / doi.org/10.1080/01441647.2020.1761907 } \\
\text { (accessed on 12 June 2021) ***** }\end{array}$ & $\bullet$ & $\bullet$ & & & \\
\hline $\begin{array}{l}\text { Bertolini, L., le Clercq, F., \& Straatemeier, T. (2008). } \\
\text { Urban transportation planning in transition. Transport } \\
\text { Policy, 15(2), 69-72. } \\
\text { https: / / doi.org/10.1016/J.TRANPOL.2007.11.002 } \\
\text { (accessed on 12 June 2021) }\end{array}$ & & & $\bullet$ & & \\
\hline $\begin{array}{l}\text { De Bruijne, Van de Riet, De Haan and Koppenjan } \\
\text { (2010) Dealing with Dilemma's: How Can } \\
\text { Experiments Contribute to a More Sustainable } \\
\text { Mobility System?. EJTIR 10(3), pp. 274-289. }{ }^{* * * * *}\end{array}$ & $\bullet$ & • & & & \\
\hline $\begin{array}{l}\text { Foxon, T.J., Reed, M.S. and Stringer, L.C. (2009), } \\
\text { Governing long-term social-ecological change: what } \\
\text { can the adaptive management and transition } \\
\text { management approaches learn from each other?. Env. } \\
\text { Pol. Gov., 19: 3-20. https:// doi.org/10.1002/ eet.496 } \\
\text { (accessed on } 12 \text { June 2021) **** }\end{array}$ & & $\bullet$ & • & & \\
\hline $\begin{array}{l}\text { Frantzeskaki, N., Wittmayer, J., \& Loorbach, D. (2014). } \\
\text { The role of partnerships in 'realising' urban } \\
\text { sustainability in Rotterdam's City Ports Area, The } \\
\text { Netherlands. Journal of Cleaner Production, 65, } \\
\text { 406-417. https:/ / doi.org/10.1016/j.clepro.2013.09.023 } \\
\text { (accessed on 12 June 2021). }\end{array}$ & & $\bullet$ & & $\bullet$ & $\bullet$ \\
\hline $\begin{array}{c}\text { Geels, F., \& Kemp, R. (2000). “Transities vanuit } \\
\text { sociotechnisch perspectief." Report for the Dutch } \\
\text { Ministry of Environment. Universiteit Twente, and } \\
\text { Maastricht: MERIT, 63. }{ }^{* * * * *}\end{array}$ & & & $\bullet$ & & \\
\hline $\begin{array}{l}\text { GEELS, F.W. (2012). A socio-technical analysis of } \\
\text { low-carbon transitions: introducing the } \\
\text { multi-level perspective into transport studies. Journal } \\
\text { of Transport Geography, 24, 471-482. } \\
\text { https: / / doi.org / 10.1016/j.jtrangeo.2012.01.021 } \\
\text { (accessed on 12 June 2021) }\end{array}$ & & & • & & \\
\hline $\begin{array}{c}\text { Geels, F.W., Hekkert, M.P., \& Jacobsson, S. (2008). The } \\
\text { Dynamics of sustainable innovation journeys. } \\
\text { Technology Analysis and Strategic Management, } 20 \\
\text { (5), 521-536. } \\
\text { https: / / doi.org / } 10.1080 / 09537320802292982 \\
\text { (accessed on 12 June 2021) }\end{array}$ & & & • & $\bullet$ & \\
\hline $\begin{array}{c}\text { Gössling, S., \& Cohen, S. (2014). Why sustainable } \\
\text { transport policies will fail: EU climate policy in the } \\
\text { light of transport taboos. Journal of Transport } \\
\text { Geography, 39, 197-207. } \\
\text { https:/ / doi.org/10.1016/j.jtrangeo.2014.07.010 } \\
\text { (accessed on 12 June 2021) **** }\end{array}$ & & & • & & $\bullet$ \\
\hline $\begin{array}{c}\text { Grin, J., Rotmans, J., \& Schot, J. (2010). Transitions to } \\
\text { Sustainable Development: New } \\
\text { Directions in the Study of Long Term Transformative } \\
\text { Change (1 edition). In, T. \& Francis (Ed.), New York } \\
\text { (Issue4). Routledge. }{ }^{* * * *}\end{array}$ & & $\bullet$ & • & $\bullet$ & \\
\hline
\end{tabular}


Table 1. Cont.

\begin{tabular}{|c|c|c|c|c|c|}
\hline \multirow{2}{*}{ References of Transition Experiments } & \multicolumn{5}{|c|}{ Typology of Approach } \\
\hline & Literature Review & Case Study & Conceptual & Methodological & Critical \\
\hline $\begin{array}{l}\text { Kemp, R, Avelino, F., \& Bressers, N. (2011). Transition } \\
\text { management as a model for sustainable mobility. } \\
\text { European Transport-Trasporti Europei, 47, 25-46. }{ }^{* * * *}\end{array}$ & & & $\bullet$ & & \\
\hline $\begin{array}{c}\text { Kemp, René; Loorbach, D.; Rotmans, J. (2007) } \\
\text { Transition management as a model for managing } \\
\text { processes of co-evolution towards sustainable } \\
\text { development. International Journal of Sustainable } \\
\text { Development and World Ecology, } 14 \text { (1), 78-91. } \\
\text { https: / / doi.org/10.1080/13504500709469709 } \\
\text { (accessed on 12 June 2021) **** }\end{array}$ & & $\bullet$ & $\bullet$ & & \\
\hline $\begin{array}{l}\text { Kohler, J. Geels, F.W., Kern, F.,Onsongo, E., Wieczorek, } \\
\text { A, Alkemaade, F., Avelino, F.,Bergek, A., Boons, F, } \\
\text { Bulkeley, H.,Hess, D.,Holtz, G., Hyysalo, S., Jenkins, } \\
\text { K., Ki, P., Markard, J. Martiskainen, M., Mcmeekin, A., } \\
\text { Muhle, M. S, .. Welch, D. (2017). STRN Research } \\
\text { Agenda-2017, December, 1-70. **** }\end{array}$ & & & $\bullet$ & $\bullet$ & \\
\hline $\begin{array}{c}\text { Liedtke, C., Baedeker, C., Hasselkuß, M., Rohn, H., \& } \\
\text { Grinewitschus, V. (2015): User-integrated innovation } \\
\text { in Sustainable LivingLabs: an experimental } \\
\text { infrastructure for researching and developing } \\
\text { sustainable product service systems In: Journal of } \\
\text { Cleaner Production, 97-116. } \\
\text { https:/ / doi.org/10.1016/j.jclepro.2014.04.070 } \\
\text { (accessed on 12 June 2021) }\end{array}$ & & $\bullet$ & $\bullet$ & & \\
\hline $\begin{array}{c}\text { Loorbach, Derk; Frantzeskaki, Niki; } \\
\text { Huffenreuter, Roebin Lijnis. Transition Management } \\
\text { Taking Stock from Governance Experimentation. The } \\
\text { Journal of Corporate Citizenship, 58, 48-66. } \\
\text { https://doi.org/10.9774/GLEAF.4700.2015.ju.00008 } \\
\text { (accessed on 12 June 2021) } \\
\text { **** }\end{array}$ & & $\bullet$ & & & \\
\hline $\begin{array}{l}\text { Loorbach, D. (2007).Transition Management } \\
\text { New mode of governance for sustainable development. } \\
\text { PhD-Thesis. University of Rotterdam. }\end{array}$ & & • & $\bullet$ & & \\
\hline $\begin{array}{c}\text { Loorbach D, Rotmans J. 2006. Managing transitions for } \\
\text { sustainable development. In Understanding Industrial } \\
\text { Transformation. (eds). Springer: Dordrecht; 187-206. } \\
\text { https:/ / doi.org/10.1007/1-4020-4418-6 (accessed on } \\
\text { 12 June 2021) }\end{array}$ & & $\bullet$ & $\bullet$ & & \\
\hline $\begin{array}{l}\text { Loorbach, D., Wittmayer, J., Avelino, F., von Wirth, T., } \\
\& \text { Frantzeskaki, N. (2020). Transformative innovation } \\
\text { and translocal diffusion. Environmental Innovation } \\
\text { and Societal Transitions, } 35 \text { (february 2019), 251-260. } \\
\text { https: / /doi.org/10.1016/j.eist2020.01.009 (accessed on } \\
\text { 12 June 2021) }\end{array}$ & & $\bullet$ & $\bullet$ & & \\
\hline $\begin{array}{l}\text { Nevens, F., Frantzeskaki, N., Gorissen, L., \& Loorbach, } \\
\text { D. (2013). Urban Transition Labs: Co-creating } \\
\text { transformative action for sustainable cities. Journal of } \\
\text { Cleaner Production, 50, 111-122. } \\
\text { https: / /doi.org/10.1016/j.jclepro.2012.12.001 } \\
\text { (accessed on 12 June 2021) } * * * * *\end{array}$ & $\bullet$ & & • & & • \\
\hline $\begin{array}{l}\text { Porter, N., Claassen, M., \& Timmermans, J. (2015). } \\
\text { Transition experiments in Amsterdam: Conceptual } \\
\text { and empirical analysis of two transition experiments } \\
\text { in the WATERgraafsmeer program. Technological } \\
\text { Forecasting and Social Change, 90(PB), 525-537. } \\
\text { https: / doi.org/10.1016/j.techfore.2014.02.010 } \\
\text { (accessed on 12 June 2021). }\end{array}$ & & $\bullet$ & $\bullet$ & & \\
\hline $\begin{array}{l}\text { Rip, A., Kempt, R. (1998). Technological Change. In E. } \\
\text { Rayner, S. and malone (Ed), Human Choice and } \\
\text { Climate Change vol.2 (pp. 327-399), Battelle. } \\
\text { https://doi.org/10.1016/B978-008044910-4.00230-3. } \\
\text { **** }\end{array}$ & & & $\bullet$ & & \\
\hline $\begin{array}{c}\text { Roorda, Chris; Wittmayer, Julia; Henneman, Pepik; } \\
\text { Steenbergen, Frank van; Frantzeskaki, Niki; Loobach, } \\
\text { D. (2014). Transition Management in the Urban } \\
\text { Context (guidance manual). Drift (Dutch Research } \\
\text { Institute for Transitions, Erasmus University } \\
\text { Rotterdam). }\end{array}$ & & $\bullet$ & & & \\
\hline
\end{tabular}


Table 1. Cont.

\begin{tabular}{|c|c|c|c|c|c|}
\hline \multirow{2}{*}{ References of Transition Experiments } & \multicolumn{5}{|c|}{ Typology of Approach } \\
\hline & Literature Review & Case Study & Conceptual & Methodological & Critical \\
\hline $\begin{array}{c}\text { Rotmans, J., Loorbach, D., \& Kemp, R. (2007). } \\
\text { Transition Management: Its origin, evolution and } \\
\text { critique (G. Workshop on “Politics and governance in } \\
\text { sustainable socio-technical transitions', 19-21 } \\
\text { September 2007, Schloss Blankensee, Berlin (Ed.)). } \\
\text { Dutch Research Institute for Transitions, Drift Erasmus } \\
\text { University Rotterdam. } \\
\text { https: / / repub.eur.nl/pub/37240/Metis_125563.pdf } \\
\text { (accessed on 12 June 2021) }\end{array}$ & $\bullet$ & & $\bullet$ & & $\bullet$ \\
\hline $\begin{array}{l}\text { Schussel, J.C. (2019). Experimenting in Palermo: The } \\
\text { pedestrianisation of its historical centre. Master Thesis } \\
\text { in Spatial Planning and Urban Project. Faculty of } \\
\text { Engineering and Faculty of Architecture of the } \\
\text { University of Oporto. }{ }^{* * *}\end{array}$ & $\bullet$ & $\bullet$ & $\bullet$ & & \\
\hline $\begin{array}{l}\text { Sengers, F., Wieczorek, A.J., \& Raven, R. (2019). } \\
\text { Experimenting for sustainability transitions: A } \\
\text { systematic literature review. Technological Forecasting } \\
\text { and Social Change, 145(September), 153-164. } \\
\text { https: / / doi.org/10.1016/j.techfore.2016.08.031 } \\
\text { (accessed on 12 June 2021) } \\
\text { ***** }\end{array}$ & $\bullet$ & & $\bullet$ & & $\bullet$ \\
\hline $\begin{array}{l}\text { Shove, E., \& Walker, G. (2007). CAUTION! Transitions } \\
\text { ahead: Politics, practice, and sustainable transition } \\
\text { management. Environment and Planning A, 39(4), } \\
\text { 763-770. https: / / doi.org/10.1068/a39310 (accessed on } \\
\text { 12 June 2021) *** }\end{array}$ & & & & & $\bullet$ \\
\hline $\begin{array}{c}\text { Smith, A., Stirling, A., \& Berkhout, F. (2005). The } \\
\text { governance of sustainable socio-technical transitions. } \\
\text { Research Policy, 34(10), 1491-1510. } \\
\text { https:/ / doi.org/10.1016/j.respol.2005.07.005 (accessed } \\
\text { on 12 June 2021) }\end{array}$ & & & $\bullet$ & & \\
\hline $\begin{array}{l}\text { STRN. (2010). A mission statement and research } \\
\text { agenda for the Sustainability Transitions Research } \\
\text { Network. Network, August, 1-27. } \\
\text { http:// www.transitionsnetwork.org/files/STRN_ } \\
\text { research_agenda_20_August_2010\%282\%29.pdf } \\
\text { (accessed on 5 June 2019) ***** }\end{array}$ & & & $\bullet$ & & \\
\hline $\begin{array}{l}\text { Van den Bosch, S, \& Rotmans, J. (2008). Deepening, } \\
\text { Broadening and Scaling up. A framework for steering } \\
\text { transition experiments. In Knowledge Centre for } \\
\text { Sustainable System Innovations and Transitions (KCT). } \\
\qquad * * * *\end{array}$ & & & $\bullet$ & & \\
\hline $\begin{array}{l}\text { Van den Bosch, Suzanne. (2010). Transition } \\
\text { Experiments. In Drift: Vol. PhD Thesis. }\end{array}$ & & $\bullet$ & $\bullet$ & & \\
\hline $\begin{array}{l}\text { Vinci, I., \& Dio, S. Di. (2014). Designing Mobility in a } \\
\text { City in Transition. Challenges from the Case of } \\
\text { Palermo. TeMA: Journal of Land Use, Mobility and } \\
\text { Environment, Vol 0, Iss } 0 \text { (2014). https: } \\
\text { / / doaj.org/article/b3fe56b2197f4b92ae5c7a05f2a0acff } \\
\text { (accessed on 12 June 2021) **** }\end{array}$ & & $\bullet$ & & & \\
\hline $\begin{array}{c}\text { von Schönfeld, K.C., \& Bertolini, L. (2017). Urban } \\
\text { streets: Epitomes of planning challenges and } \\
\text { opportunities at the interface of public space and } \\
\text { mobility. Cities, 68, 48-55. } \\
\text { https: / / doi.org/10.1016/j.cities.2017.04.012 (accessed } \\
\text { on 12 June 2021) }\end{array}$ & & & $\bullet$ & & \\
\hline
\end{tabular}

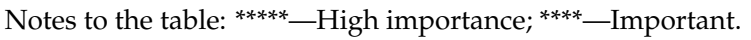

Table 1 shows the selection of the most important publications after reading and synthesizing the 118 publications. The selection in Table 1 corresponds to the references classified as "Highly Important" or "Important" for the research. This classification took into account the research question, so it considered the most relevant publications to the object of investigation, and of these, the most recent and the most cited were selected. This selection also ensured a diversity of publications for each type of research approach systematized above. It should be noted that this selection did not imply that we disregarded, at all, the remaining publications classified as of "medium importance" or "little importance" for the research, but rather, it allowed us to give relevance to those that revealed themselves as determinant for the research. 


\section{Concept of Transition Experiments}

\subsection{Concept Origin}

The concept of Transition Experiments (TE) [13,24-27] emerged after the introduction and diffusion of the concept of sustainable development, in 1989, with the Brundtland report and was developed in the last two decades. Thus, in 2001, the concepts of Transition Experiments and/or Transition Management were introduced in Dutch legislation ([28], p. 44) associated with the sustainable development debate and complex social issues derived from unsustainable and persistent problems in order to accelerate systemic and disruptive changes [29]. The fourth National Environmental Policy Plan (NMP4) was a revolutionary policy document because it placed the transition process as a political priority in the Netherlands and broke with dominant practices. In this sense, it created space for innovative policy experiments in transition management that integrate the interaction between researchers and administration officials ([19], p. 3). This moment gave rise to a field of interdisciplinary research on these concepts and approaches that grew rapidly and intensely both in literature and practice, particularly in the Netherlands, Belgium, and the United Kingdom [19]. It was in this context, during the 1st European conference on transitions towards sustainability, held in 2009, the Sustainability Transitions Research Network [27] was inaugurated.

As a result, Transition Management has been applied in the Netherlands, in an articulation between theory and practice, at various levels of intervention (e.g., at national and regional levels and in innovation programs at the project level, such as "Transumo" and "People Movers") promoting the development of debate and knowledge in this field and the consolidation of a "transition community" made up of researchers, technicians, and politicians ([7], p. 5).

In recent years, the United Nations Convention on Biodiversity, the European Environment Agency, the Organisation for Economic Co-operation and Development (OECD), and the United Nations, among others, have launched reports and policy programs in support of sustainability transitions with the argument that systemic change is necessary if ecological sustainability thresholds are not to be exceeded by 2050. Thus, the perceived inability to achieve these outcomes through incremental strategies, despite ambitious policy commitments and heavy investments, leads us to the need to apply sustainability transitions approaches ([21], p. 251).

\subsection{Concepts}

In this context, and for our case study, there are researchers who have addressed the application of Transition Experiments towards Sustainable Urban Mobility [1-14,30], in order to cope with the inertia, uncertainty, and complexity of the theme; they intuitively perceived the need to proceed with innovation management through the interaction between different actors, the same actors who, in turn, condition and influence the desirable systemic changes.

Transition Management is a deliberate process of influence and persuasion through metagovernance that promotes interaction between the market, the state, and civil society, and also combines the advantages of incrementalism with planning and promoting the acceleration of changes towards sustainability in place of unsustainable dominant practices ([19], pp. 5, 24, 25). Transition Management aims at the consolidation of a procedural approach framed in a context of uncertainty geared towards the achievement of goals [31]. The agents involved in the process will determine it, and, in general, the actors with power are recurrently adverse to disruptive and rapid transitions ([29], p. 50). The complex and uncertain context of the transition approach prevents a direct orientation, but due to the inherent degree of adaptation, the triggering crises constitute windows of opportunity for an accelerated reorientation towards sustainability ([29], p. 49).

According to Rotmans et al. ([19], p. 21), the focus of Transition Management consists of

- Exploring the persistence of a problem and recognizing that there is no preconceived solution;

- Transforming the problem into a vision that encompasses a diversity of options;

- Carrying out small-scale experiments; 
- Making informed choices based on learning experiences with small-scale experiments (scaling-up experiences).

On the other hand, Loorbach \& Rotmans ([32], p. 10-11) define seven key elements of Transition Management:

- Systems-thinking (in terms of multi-domain, multi-actor, and multi-level, trying to change the strategic orientation of regime actors);

- $\quad$ Long-term thinking (at least 25 years) as a framework to shape short-term policy;

- Short- and long-term goals based on long-term sustainability visions, scenario-studies, trend analysis, and short-term possibilities;

- Focus on learning ("learning-by-doing");

- Orientation towards innovation and experimentation;

- Learning about a variety of options;

- Stakeholder participation and interaction.

Thus, the concept of Transition Experiments stems from the methodologies of the transition economy and foresees the application of participatory approach tools, in microscale interventions, in order to influence and accelerate transitions towards Sustainable Development (covering its economic, social, and environmental components). It consists of a methodology for accelerating socio-cultural transformation processes in terms of sustainability of which the long-term results are known to the urban planner/designer (e.g., decarbonization goals defined in the Paris Agreement for 2050), but which are envisaged to take place in the short term.

"Transition management aims at system change, while policy making is mostly about incremental change." ([26], p. 20).

To this end, we must recognize that today there is an increasingly clear and widespread awareness of the urgency of the effectiveness of transformative processes, and rather than the urgency of their implementation, the need to anticipate them, especially with regard to environmental factors, due to their recognized implications in the extension of public health, global poverty, the decrease of biodiversity, and even the very survival of the human species in the long term.

In fact, Transition Experiments (TE) are not compatible with superficial changes and are more than projects. More than reflection processes, TE represent a new attitude and a way of being in front of recognized problems. They are disruptive actions, tested in a certain area of the territory considering the interaction with the main agents interested in these actions, and have as main objective to accelerate in the short or medium term a change that represents the achievement of a long-term goal. Transition Experiments are thus tools of the Transition Management approach itself and provide a pragmatic framework to influence, support, and accelerate transitions [26].

"Developing transition experiments is a balancing act between radicality and feasibility.

The projects should be 'business as unusual' and challenging the status quo, and at the same time viable and visible. " ([26], p. 31]).

TE are tested in Real Life Labs, which behave as incubators of sustainable urban innovation in a given territorial and social context and aim to achieve a structural social transformation challenge through research, action, and innovation processes [22]. This experiential learning, through provisional activities and whose results are unknown at the outset, enhances a new social practice through the "learning by doing" methodology ([12], p. 161). In this sense, TE are intrinsically related to an action-research methodology [13] applied to a laboratory in a real-life context that, through a monitoring process, articulates theory with practice in a logic of continuous improvement. In this sense, the researcher combines the reflective and the participatory role ([28], p. 26).

One of the instruments to put these experiences (or long-term social learning innovation projects) into practice are the transition arenas applied in a non-linear process that includes procedures such as the constitution of a diversified transition team, the empower- 
ment of actors, the strengthening of collective spirit, reflection on analyses, the constitution of change scenarios, and continuous involvement and evaluation [26].

In short, as Nevens ([22], pp. 111, 112) states, cities are the logical physical space for promoting sustainable development, Transition Urban Labs are the appropriate settings for this purpose, and local communities are the scale at which behavior can be most directly influenced.

These are concepts that, in our perspective, are embodied in the definition of unavoidable fronts where action can and should be applied and in the coherence that these should have as defined by the long-term structural transformations. First and foremost, the definition of a strategic line is assumed by all the intervening parties, as no strategy can succeed unless it has a broad base of consensus.

In truth, when the modern era is still to be fulfilled and immediate demands need to be met in the short term, we are fully aware of the existence of a wider range of constraints hindering the desirable transition.

In fact, there is a difficulty in solving persistent problems related to unsustainable practices of today's society through traditional planning approaches [32].

\subsection{Characteristics of Transition Experiments}

Transition Experiments, using research, learning, and experimentation, incite social change to combat persistent problems and needs that have become unsustainable [28]. Thus, in continuity with Loorbach \& Rotmans' ([32], pp. 10-11) systematization, Van den Bosch ([28], pp. 26, 58-59) argues that TE should encompass the following characteristics:

- $\quad$ Be an innovation project (radical system innovation that changes the relationship between organizations and individuals) with the potential to contribute to a sustainability transition;

- Provide a connection to a long-term social challenge (related to the resolution of a persistent social problem);

- Focus on interactive learning to obtain further knowledge, skills, norms, and values and achieve changes in structure, culture, and practices.

Regarding the concept of learning, which is intrinsic to Transition Experiments, this can be achieved on several scales [13]:

- Learning within the same interest group through the interaction of the actors and their points of view;

- Staggered learning within the administration, from the bottom, up to the decision-makers;

- Learning within the territorial context through knowledge transfer from one experience, from one laboratory area to another, and/or participation in transnational networks.

STRN [27] advocates the need to distinguish between innovation processes and overall social transitions and emphasizes the importance of the interconnectedness of actions in the process of Transition Experiments to influence the socio-technical change at stake. The evaluation of this transition governance focuses both on the speed and the direction of the transition.

It is in this respect that the vision of Roorda et al. ([26], p. 10) may help us to outline the way forward when defining six principles to influence transitions:

- To have an overview (to be aware of the complexity of the challenge in its different domains);

- Innovate by taking small but radical and long-term steps;

- Make room for diversity and flexibility (facing uncertainty and foreseeing resistance);

- Co-create (involving multiple stakeholders in decision making);

- Make room for agents of change (consisting of actors who are receptive to change and who have the capacity to innovate and to influence mediation);

- Valuing the social and institutional learning process (the learning process of all involved, including administration, is essential for the reflection and achievement of social change. In this sense, it is important to be receptive to different perceptions of challenges and opportunities in a spirit of mutual trust). 
The operationalization of these principles is carried out by means of four types of interventions ([26], pp. 10-11).

- Orientation (defining the challenge and building capacity for the transition);

- Agenda setting (consensus for sustainability);

- Activation (implementing projects and learning from them);

- Reflection (fostering a culture of reflexivity, learning, and continuous improvement).

The key outcomes of this approach are the establishment of consensus for a sustainable future and a drive for local change and collective 'Empowerment' ([26], p. 12). In this sense, the Transition Arena constitutes the informal and temporary space in which these four types/phases of intervention are applied. In the transition arena, the agents of change, through the holding of meetings, determine the foresight and reflection of an ambitious and innovative systemic change challenge and the actions of the transition agenda to be implemented in the short-term, but which contemplate a long-term vision. This transition agenda is inspired by and integrated with ongoing experiences and consistently structures the Transition Experiments to be applied and expanded ([19], p. 7). Indeed, the transition agenda inspires transition by defining strategies, pathways, and objectives that guide the actions of different actors ([22], p. 119), but these elements, which guide a vision of a sustainable future, are not elaborated in a deterministic way. Rather, they constitute evolving future scenarios, in which goals and pathways guide a social learning that may entail respective adaptation at various moments and stages of the Transition Management process cycle ([19], p. 7).

"So visions and transition processes are mutually dependent: visions are guiding in transition processes but transitions do also co-shape the visions developed." ([19], p. 8).

The consolidation and publication of the vision and sustainability agenda constitute the factors of commitment of the different actors for successful Transition Experiments [33]. The next step is to involve a wide diversity of new transition actors and collaborative networks forming new coalitions (transition experts and external facilitators) to rethink and reorient current practices and to press forward in the political and market arena ([29], p. 55). The selection of actors to be part of the transition team is made upon the suggestion of other team members, and their participation is considered on an individual basis, in an open spirit to new perspectives, and not in the representation of the associations or institutions to which they belong. However, the personal experiences and skills of these actors are considered, with the aim of conferring diversity to the team. Transition Experiments are therefore aimed at defining a team of transition agents in a way that is oriented towards future development and not just involving stakeholders or representing a part of the population.

Empowering agents for transition is another important step to take into account in the process to increase the contribution of new transition agents, and learning and reflection are the crucial tools for addressing Transition Experiments [26].

The consolidation of Reflective Governance, using monitoring and evaluation, contributes to political and social learning and the adaptation of experiment-based sustainability practices ([33], p. 414).

Continuous monitoring is thus a key feature of TE and should integrate the various stages of the process, namely ([29], pp. 55-56):

- Monitoring of behaviors, projects, network activities, and the responsibilities of stakeholders in the transition arena;

- Monitoring of actions, objectives, projects, and instruments foreseen in the transition agenda;

- Monitoring the rate of progress, barriers, and improvement points of the transition process itself.

\subsection{Types of Transition Experiments}

Transition theory distinguishes two subfields: Transition Dynamics and Transition Management. Transition Dynamics aims to understand how transitions in social systems arise. 
Using the multi-level perspective [34], transition dynamics include the interaction of three different levels of scale (Figure 2): macro (landscape/social system environment), meso (regimes), and micro (social niches). Change occurs through processes of coevolution and mutual adaptation between these levels [20]. According to Foxon ([31], p. 5), radical innovations are generated at the micro level, in the niches of intervention, given that at the level of the existing regime innovation is merely incremental. At the micro level, social subsystems are thus identified, designated as niches, which challenge and deviate from the dominant regime or structure, in a context of experimentation towards new sustainable practices and cultures, through a process of reciprocal learning. The changes that occur in the niches shape and reshape the regimes (at the meso level) and landscapes (at the macro level) that sustain each other reciprocally, in a logic of rise and fall of socio-technical systems and regimes [20]. When these three levels, by interaction, strengthen themselves in the same direction, we may assert that the transition occurs.

\section{PROCESSES OF COEVOLUTION AND MUTUAL ADAPTATION BETWEEN THE MACRO, MESO AND MICRO LEVELS}

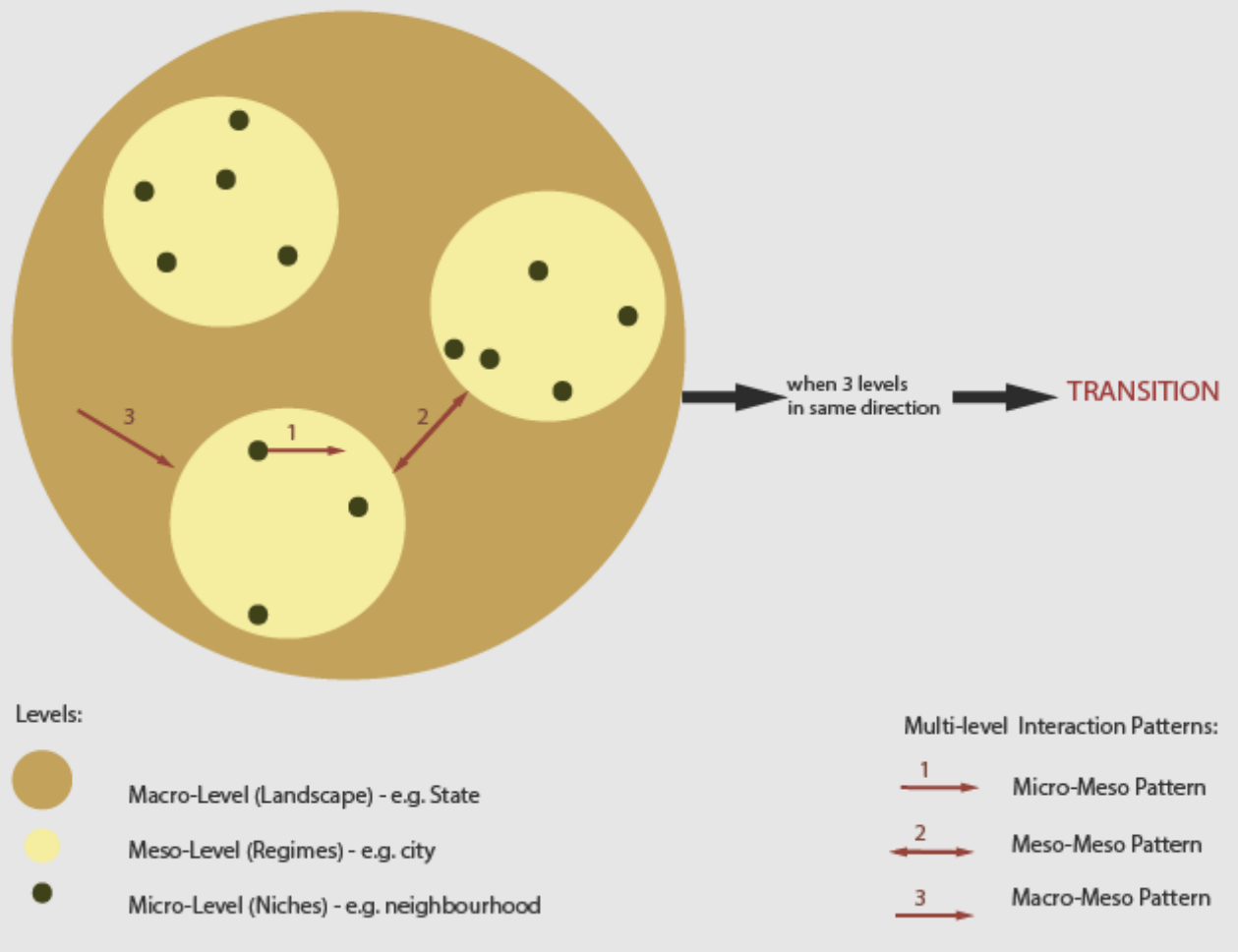

Figure 2. Multi-level perspective. Elaborated by the authors.

According to Rotmans et al. ([19], p. 19), in Transition Dynamics, three variants of generic patterns can occur: Micro-Meso pattern, Meso-Meso pattern, and Macro-Meso pattern. In the first, niches emerge at the micro-level (e.g., at the neighborhood/borough scale), group together, and form a niche regime that influences the prevailing regime promoting transition. In the second, niches emerge at the meso level (e.g., at the city level influencing urban culture), defining a new regime within the existing regime that will influence and change it. Finally, the Macro-Meso pattern constitutes a rapid change of the existing regime, imposed by overwhelming pressure (e.g., imposed by the State, or at the European or world level as a response to a pandemic, or any other calamity).

Hence, the leverage that influences transition processes can occur through the clustering of niches that forms a niche regime and influences the transformation of the dominant regime into the new regime or through a rapid and massive change at the macro level, which leads to severe pressure on the regime and consequently to its change. 
Transition Management is a new mode of governance that aims to develop multidisciplinary, theoretical, and practical knowledge, involving researchers and social stakeholders, to influence transitions towards sustainability ([28], pp. 38-39), ([35], p. 17).

Transition Management presents an approach of exploratory learning and co-creation, given that the solution is not patent at the outset, and is a selective process in terms of the stakeholders it involves, highlighting the role of pioneering agents (external to the regime and prone to innovations for sustainability).

Nevertheless, we can already consider experiences in this domain. Sengers et al. [12], based on previous research and alongside other authors [11,13], define the five most recurrent types of Urban Experiences on sustainability transitions (Table 2):

1. Niche Experiments (NE) 1998

Niche experiments were developed in the 1990s and are based on the opportunities that new technologies confer towards sustainability. The main stakeholders are outsiders.

Table 2. Conceptual synthesis of urban experiences for sustainability transitions. Elaborated by the authors based on Sengers [12].

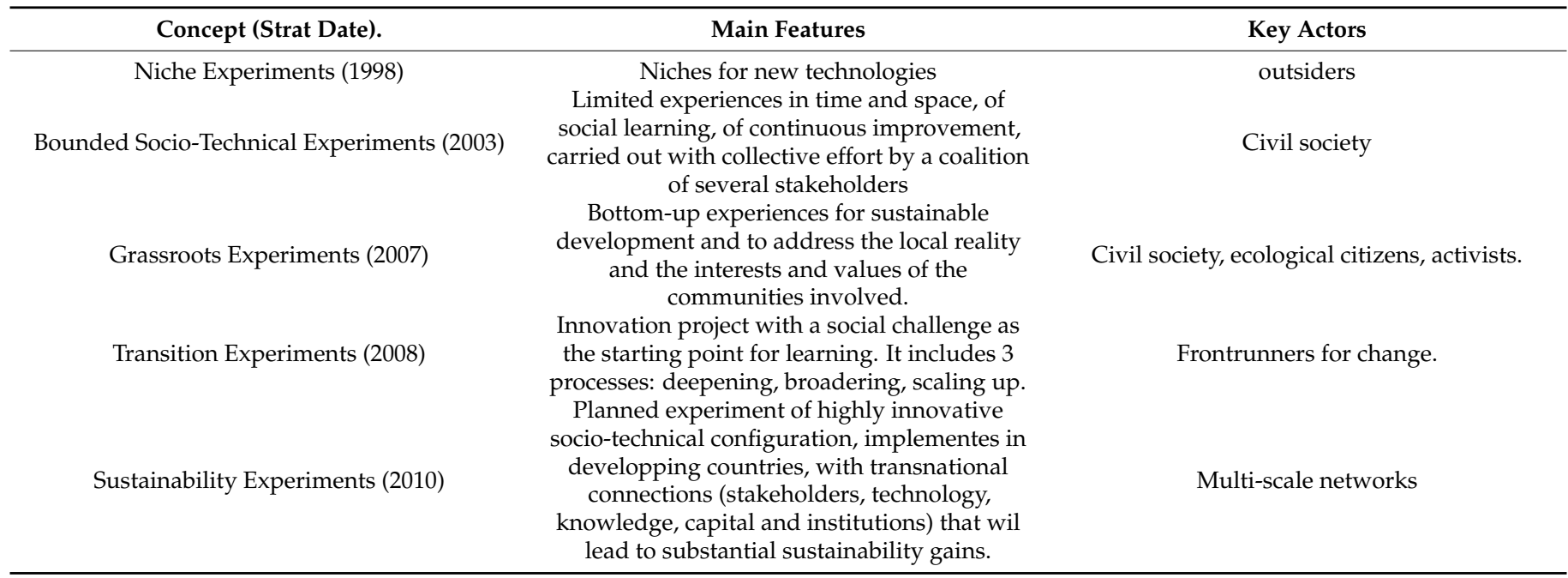

\section{Bounded Socio-Technical Experiments (BSTE) 2000}

The bounded socio-technical experiences arise from the year 2000, as a criticism to the central focus on technology, of the niche experiences. They are social learning processes that contemplate geographically delimited and small dimension societies, with the continuous improvement process developed in around five years.

\section{Grassroot Experiments (GE) 2007}

Grassroots experiments are actions developed at the bottom-up level, by activists, cooperatives, associations, companies or community groups that come together for sustainable development. It is a collective action to build a community in a learning process that integrates the triple tension of Hossain (2018), i.e., environmental, social, and economic benefits.

\section{Transition Experiments (TE) 2008}

Transition experiments explore the persistent needs and problems of society in a proactive and radical way, aiming to influence and steer transitions. These experiments give increased importance to pioneers (agents of change, innovators, and visionaries) who should not be direct stakeholders (neutral agents) but should be strongly committed to sustainability challenges.

Transition experiments provide a framework to influence, support, and accelerate transitions and connect urban policies with innovative practices of other local agents. These experiences reconcile the theoretical framework with the practical process leading 
to the rethinking of the administration 's modes of working. Transition experiments assume a balancing act between radicalization and feasibility, thus drawing on existing dynamics and reorienting transition objectives selected by society in a flexible process of continuous improvement.

\section{Sustainability Experiments (SE) 2010}

Sustainability experiments are initiatives planned to achieve substantial sustainability outcomes, are highly innovative and take place in a particular social context, especially in developing countries but using transnational connections (enhancing and complementing local capacities and resources) ([12], p. 158-159).

Therefore, sustainability experiments have four main characteristics: they are planned; they are tests for highly innovative sustainability ideas; they are geared towards high environmental gains; and they can be bottom-up or top-down.

\subsection{Transition Process}

In the Transition Management cycle [13], four groups of activities are distinguished (Figure 3) that incorporate and link a range of instruments at the strategic (e.g., activities that drive the sharing of ideas and the creation of a common vision of the problem), tactical (e.g., development of images and pathways that direct different Transition Experiments and provide a basis for cooperation), and operational level (e.g., mobilization of stakeholders and the creation and execution of Transition Experiments with the aim of transforming visions and agendas into concrete actions).

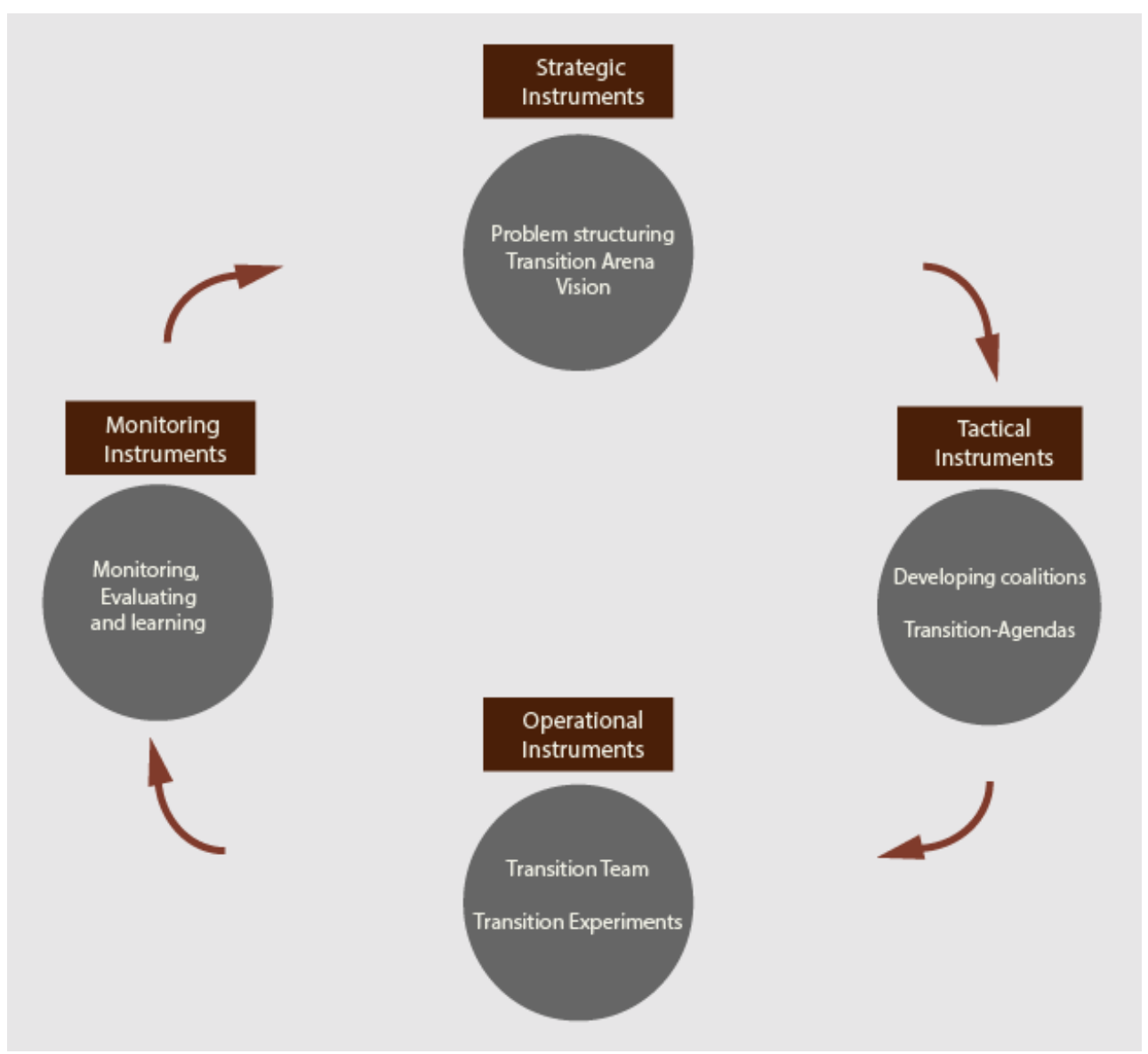

Figure 3. Transition Management Cycle. Elaborated by the authors based on Van den Bosh \& Rotmans [13].

In order to systematize the Transition Experiments process, Roorda et al. ([26], p. 15) structured it into the following seven phases: 
1. Prepare the transition scenario

At the beginning of the process, a transition team is formed, with three to five members with complementary functions as well as skills in communication and social interaction. This multi-sectoral and representative team is responsible for planning and conducting the process, namely, the organization of communications, logistics, division of tasks and responsibilities, involvement with other external stakeholders, planning reflection meetings, and defining the necessary human, economic, and time resources.

The articulation with political and local public administration figures, through interdepartmental meetings in the transition arena, is important both for the need to commit and to support the process and to create synergies for other initiatives.

In this phase, the focus of the problem to be addressed is defined, in addition to the plan of the process that will be adapted in the following phases that contemplate the group dynamics of the transition arena in a collaborative and flexible environment ([26], pp. 16-17).

The definition of goals, (achievable but challenging) objectives, strategies, and criteria requires negotiation of the parties involved through the sharing of knowledge and views and the consolidation of an integral and consensual perspective of the process ([4], p. 280).

\section{Exploring local dynamics}

The transition team explores the local dynamics through interviews and document searches and prepares a system analysis, which aims to build an integrated overview of the context, as well as through an actor analysis, which aims to map the relevant stakeholders to be involved in later phases [26], p. 20).

Systems analysis takes into account various sources and includes the assessment of social, economic, spatial, environmental and ecological aspects.

Actor analysis is developed in three phases ([26], pp. 21-23):

1st-creation of a list of potential stakeholders that fit the problematic and the objectives of the approach in question;

2nd-The candidates are then categorized by different backgrounds (e.g., institutions, companies, citizens), capacities (e.g., leadership, creativity, analytical skills, social skills), interests (e.g., climate, energy efficiency, ecology, sustainable mobility, transport), and types of power (e.g., innovative power, transformative power and the ability to mobilize others for change, and reinforcing power through dominant hierarchical position). At this stage it becomes clear which categories and profiles may be missing in the team to ensure diversity.

3rd-Lastly, actors are selected (10 to 15) who will join the transition team on an individual and non-institutional basis or as stakeholders. According to De Bruijne et al. [4], this condition allows developing more daring and riskier and less conventional experiments.

The involvement of external stakeholders (for independent evaluation) and neutral stakeholders increases the opportunity for the implementation of radical innovations ([4], p. 280).

Communication (e.g., leaflets, websites) is an essential part of the transition experience to capture stakeholders and to disseminate the developed practices and the process with the record of meetings, dilemmas, and visions and with the developed prototypes, which should be compiled for further reconstruction of the process, contribution to knowledge, and support towards research ([4], p. 280).

3. Addressing the transition challenge

Transition arena meetings provide concrete guidance for cultural change that starts with systems analysis (one or more meetings). The shared framing of the problem and the interaction of the various perspectives and domains may be accomplished through presentations in the transition arena, enhancing the sense of urgency and the gradual convergence into a collective commitment ([26], pp. 23-24).

\section{Creating the vision of a sustainable city}

To illustrate the transition challenge shared and outlined in the previous phase, visionary images are created of the future that the outlined challenge intends to achieve.

5. Relate the short term and long term 
After establishing consensus on the foresight, that is, the vision of the future, (one or more) meetings are held to establish the path towards achieving this future through short-, medium-, and long-term actions. Various paths are identified, discussed, and prioritized by the arena group.

After this phase, the ideas are published in the transition agenda, co-authored by all transition actors, which can be in the format of a book, magazine, cards, or other and in which the transition challenge and the actions and the visionary images developed in the transition arena that constituted the starting point for change are summarized.

The transition agenda will strategically and flexibly guide future development and ensure the commitment of the parties to the established consensus. Working groups can be created to operationalize the vision of the future in the short, medium, and long term. The future vision guides short-term actions and is an important tool in communicating with a wider audience ([26], pp. 23, 27, 30,34).

Each of the phases of the Transition Experiment should embody a set of pre-established procedures and rules, albeit incorporating some flexibility that may be managed by the transition team members responsible for planning and conducting the process and who may adapt the design of the Transition Experiment during the course of the monitoring process ([4], p. 282). The projects aim at incorporating the Transition Experiment into a broader systemic project and should address an interface between innovation, institutional, and technical environment ([4], p. 283).

\section{Engage and Anchor}

In this phase, the transition agenda is published and disseminated. After the publication of the transition agenda, the transition arena is preempted for the sake of engaging with a wider public, which may start with extended or more restricted events where agents present the agenda to their networks of relations. This process aims to consolidate a group of ambassadors with the capacity to develop emerging ideas and embed them in day-to-day practices involving their social networks through their capacity of influence. The aim is to maintain the pace and motivation of the challenge launched and to extend and expand it by involving more and more people ([26], pp. 23, 35).

As the experience is developed, the relevance of articulating it with other experiences and with new stakeholders is identified ([4], p. 282).

\section{Taking action}

The proposed short-term implementation actions, as well as new actions aligned with the agenda, can take place in parallel to the dissemination actions of the transition agenda. Learning, reflection, and monitoring of actions remain important at this stage ([26], p. 41) The main purpose of monitoring in Transition Experiments processes is to trigger action and optimize the change process (not only to measure), and parts of these monitoring processes are participatory ([22], pp. 115, 120). According to Nevens et al. ([22], p. 115), change occurs from the incorporation of different transition activities through to the implementation of corporate strategies and the application of policy, legal, and citizen behavioral changes.

The main objective of Transition Experiments is to boost a fundamental change in a regime (or dominant structure) at the cultural level (awareness of the need for change and incorporation of a new sustainability discourse), at the practical action level (new ways of acting and new routines), and at the structural organization level (contemplating changes in financial, political, and legal priorities in favor of sustainability). This change takes place through cycles of [13]:

- Deepening (social learning process arising from experience and interaction in a specific context that includes cultural, practical, and structural changes);

- Broadening (learning from similar experiences applied in new contexts and/or domains);

- Scaling up (learning by increasing the scale of the problem from local to global, incorporating new methodologies of practical approach and a new culture). 


\section{Public Involvement}

Local authorities have a determining role (at the financial, licensing, enforcement, and organizational levels or in the involvement of different partners) in pursuing the processes of promoting sustainable development and integrating converging policies towards this aim ([33], p. 414). Fostering collaborative governance and corporate learning within Transition Experiments, Frantzeskaki et al. ([33], p. 415) and Loorbach et al. [29] argue for the constitution of meta-governance (involving local government and different partners), without neglecting the political and social responsibility of local government. In other words, the constant need to reflect the implications of representative versus participatory democracy. The focus on meta-governance implies having a long-term system vision (at least 25 years) to guide short-term policy with immediate and effective intervention in a delimited and protected environment for innovation that relies on stakeholder involvement, participation, and interaction and results in a permanent social learning process. In this sense, Nevens et al. ([22], p. 120) consider that applying Transition Management in a local municipality policy setting is a transition in itself because of the need for openness to different approaches and attitudes, from all types of local actors, and for the cooperation of local authorities in fitting into a co-creative and mutually trusting process, foregoing control of matters and drawing on facilitator, enabler, and connector roles. Thus, Transition Management embraces the combination of elements of top-down (in the process of anticipating and building the transition agenda) and bottom-up (in the process of learning and experimentation) approaches ([19], p. 7) which results in a side-by-side logic.

The governance of regime transformation depends [36] on the degree to which the pressures of ideological change are articulated and the capacity for innovation and adaptation that are available for the regime to be able to respond to these pressures explicitly. Adaptive capacity (a concept from the literature stemming from climate change, in IPCC, 2006), in turn, is conditioned by the availability of resources necessary for effective transformation and the ability to coordinate responses to pressures in a coherent manner among regime members.

The transition context, according to Smith et al. [36], depends on the degree of coordination between pressures and the locus of adaptive resources (internal/external), with these authors defining four types of context according to these two variables (Figure 4):

1. The transition context that [36] call "Reorientation of trajectories" corresponds to that which has the internal locus (top-down measures) and low coordination in the responses to the challenge. In this type of context, there is a high degree of unpredictability regarding the direction in which the interaction will take place due to the lack of coordination in the adaptive capacity to respond to the pressures and the power inherent in the locus of resources (internal regime).

2. The transition context "Endogenous Renewal", similar to the first one, has the locus of internal resources (top-down measures), but it presents a high coordination in the direction of the adaptive response. This type of context tends to promote an incremental change, and the decisions are often related to previous experiences; therefore, in general, they do not correspond to such radical changes as in the other contexts.

3. When pressure arises from resources outside the established regime (bottom-up measures) and these present a low coordination in response to pressure, we are dealing with a transition context defined as "Emergent Transformation". The lack of articulation in these cases, with more limited power than in the first, generates uncertainty in the governance process.

4. Finally, in cases where the pressure comes from outside the regime (bottom-up measures) and in a very coordinated and explicit manner from social interests ("Purposive Transitions"), this results in the management of the transition based on negotiation and the attribution of a more relevant role to external stakeholders. 


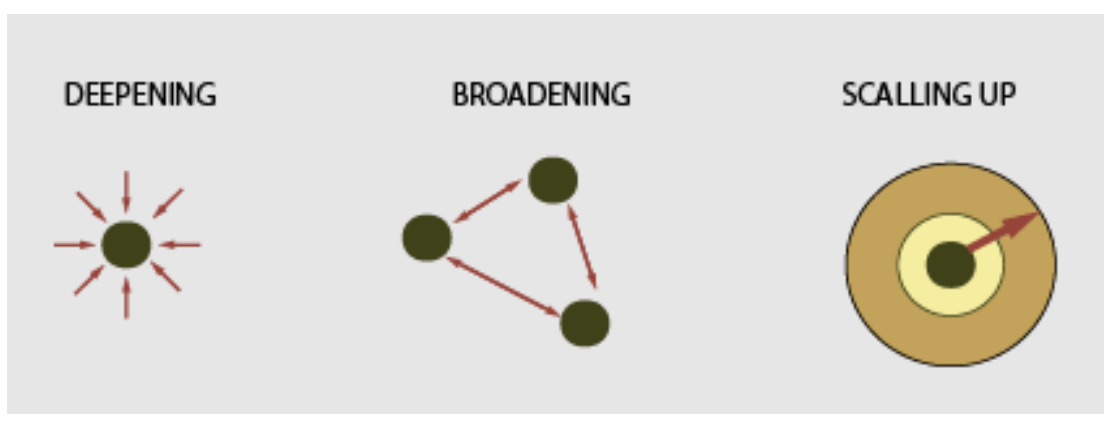

Figure 4. Deepening, Broadening, and Scaling-up in the Transition Experiments in relation to a multilevel perspective. Elaborated by the author.

This process aims to promote a participative citizenship in innovative and sustainable matters, which are not yet consensual for the population, such as the promotion of Sustainable Urban Mobility (and as an example, in the near past, the process of waste recycling).

\section{Urban Design of Public Space}

The systematization in 3D theory (Diversity, Density, and Design) presented by [37-43] corroborates the thought that the constructed environment influences commuting and vice versa. Urbanism thus begins to integrate Mobility as its own substance in architectural design [44], replacing the concept of a road network segregated from zoning [45]. This theory, of the symbiosis between Architecture and Mobility, was later tested and synthesized by Manuel Solà Morales [46], who attributes to architecture the role in controlling the impact of flows in public spaces that stimulate social practices [16].

Public space, being composed of a variety of forms, such as squares, parks, and streets, is a crucial element for social change, as it is in public space that people move around and exercise or connect to various activities ([47], p. 49).

According to Porter ([48], p. 526), transition experiments are innovation projects with a social challenge that fit design features and criteria. However, he considers that little has been published on the analysis of examples of real experiences and on the validity of these design criteria for the experience of governance of social transitions.

In the examples of Transition Experiments for the benefit of the paradigm shift towards Sustainable Urban Mobility, there is a tactical redistribution of public space, increasing the space allocated to soft modes through the strategic and temporary placement of street furniture in public space. The Leefstraat project in Ghent involves the ideas of inhabitants who are assisted in the design and implementation [26], ([47], p. 52).

The pioneering agents are the creative designers of the vision ([22], p. 118), but this vision, in the Transition Experiments (TE), is elaborated in co-creation. In this sense, Nevens et al. ([22], p. 120) note that the process of reflexive monitoring of TE involves a continuous willingness to redirect, rethink, and redesign.

According to De Bruijne et al. [4], the design of Transition Experiments should incorporate the various stakeholders and reach a unanimous agreement on the learning objectives of the Transition Experiment. On the other hand, reflexive governance, aiming at the involvement of all stakeholders, advocates monitoring the design principles of ongoing and future projects ([33], p. 415). Foxon ([31], p. 12) also used computer models to build a detailed picture of possible scenarios that are updated with the stakeholders' contributions. This tool proves to be useful for anticipating solutions and models that test the social acceptability and respective viability of the proposed innovations.

\section{Expected Effects of Transition Experiments for the Promotion of Sustainable Urban Mobility Interventions}

Sustainable development implies a change in behavior, and psychology emphasizes the importance of sharing information and educating and involving the population through 
awareness campaigns. Similarly, behavioral economists advocate the application of taxes and subsidies to steer the behavior of the population through a cost-benefit logic. In this sense, the Transition Experiments advocate the institution of substantial changes in the socio-cultural and institutional structure and the implementation of new practices and routines for sustainability ([27], p. 5). Indeed, the concept of TE is closely related to changes at the structural level (physical, institutional, and economic), at the cultural level (society's norms, values, and thoughts), and at the level of practices (routines and behaviors), and the new practices have the potential to influence the installed structures and cultures and vice versa $[28,49]$.

Considering the multi-level perspective discussed above (macro level of the social system environment; meso level—regime; micro level—niches), Van den Bosch ([28], p. 42) considers that constellations (of structures, cultures, and practices) interact and have the capacity to influence transitions, and that it is at the level of niches that changes are easier and quicker to operate. As for change at the macro level, this only takes place in the long term (through the interaction of the other two levels) or through shocks (e.g., disasters, crises or other types of impositions).

By combining the multi-level perspective with the mechanisms of deepening, broadening, and scaling, the desired transition towards a new (more sustainable and dominant) balance in social dynamics in terms of thought and practices, and the organization of structures is achieved (Figure 5).

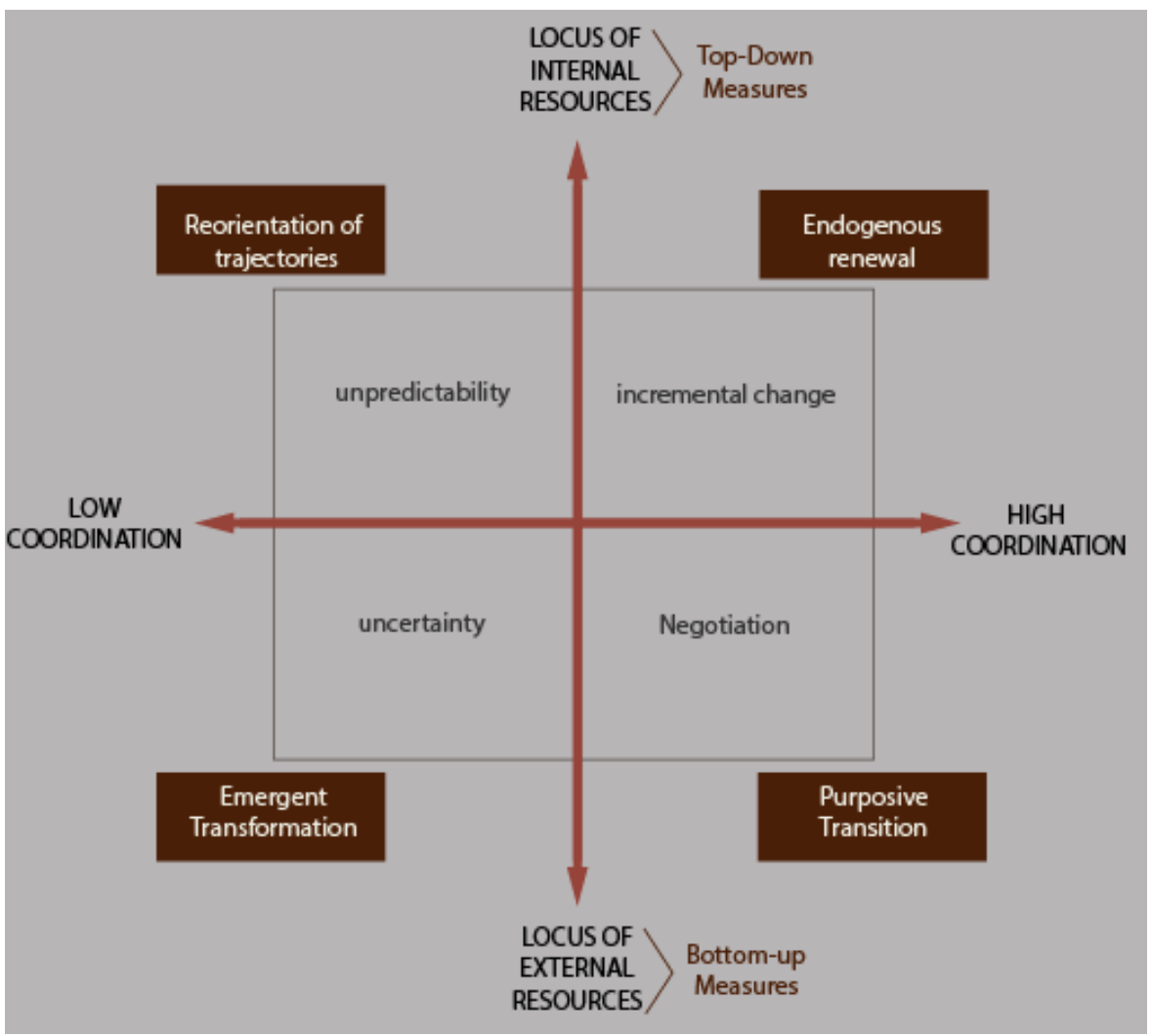

Figure 5. Transition contexts according to the degree of Coordination and the locus of the sources. Elaborated by the author based on Smith et al. [36].

Van den Bosch ([28], p. 42), based on Rotmans et al., 2001, draws on the multiphase concept to describe the temporal dynamics of transitions, which is divided into the following phases:

1. Pre-development phase (dynamic balance);

2. Take-off phase (start of the changeover) 
3. Acceleration phase and collective learning (structural changes through the accumulation of socio-cultural, economic, ecological, and institutional changes)

4. Stabilization phase (the speed of change slows down and a new state of equilibrium is reached).

Figure 6 illustrates the non-linear pattern of the various phases of the transition dynamics (fast and slow phases) based on the multiphase concept. In the first phase (predevelopment phase), there are no significant changes. These only start to be felt in phase 2 , the take-off phase, becoming visible in phase 3 , the acceleration phase, in which collective learning and diffusion processes bring about socio-cultural, economic, ecological, and institutional changes. When the transition change is achieved, the stabilization phase is reached, corresponding to a new dynamic equilibrium and a new regime ([28], p. 42). Thus, Van den Bosch ([28], p. 42) argues that transitions consist of the change from one dynamic equilibrium state to another.

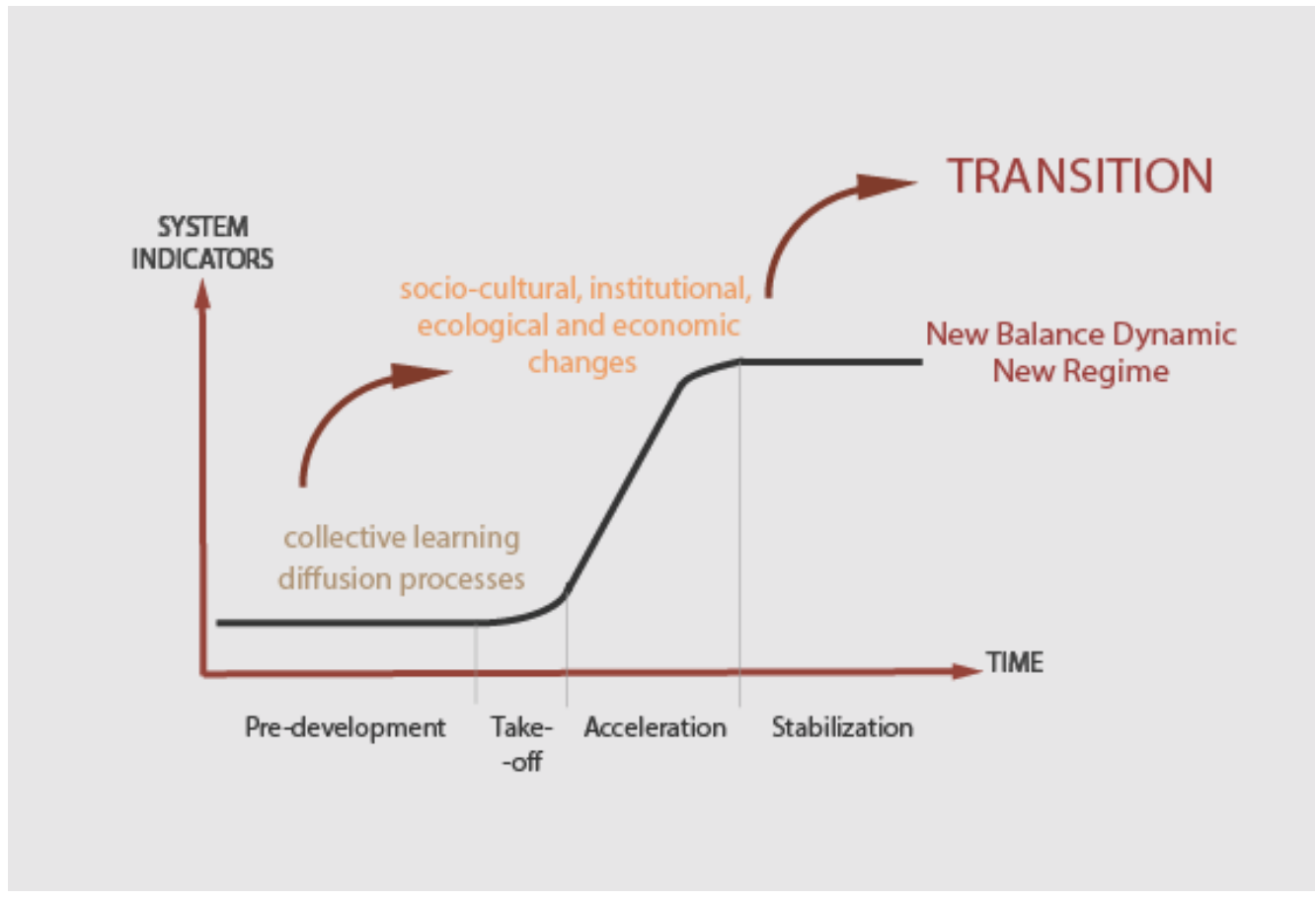

Figure 6. Multiphase concept. Elaborated by the authors based on Van den Bosch ([28], p. 42) and Rotmans et al. ([50], p. 17).

To analyze transition dynamics, Van den Bosch ([28], p. 43) also draws on the concept of multi-patterning, which is based on three transition patterns:

1. Empowerment-which is the capacity to influence and empower small niche constellations to compete with the incumbent regime.

2. Reconstellation-which contemplates influences from outside the social system and results in a viable alternative to the current regime.

3. Adaptation-occurs when the current regime adapts to some functional aspects of other constellations.

\subsection{Effects on the Culture of Mobility}

Transition Experiments trigger a methodology of reflection on challenges for the future of the city that denotes a potential to inspire organizations (e.g., local government, politicians, and officials) and the population to change their policies and behaviors ([29], p. 53). According to Roorda et al. ([26], p. 18), as the effects become clearer, attitudes towards the process are more positive. The tangibility of short-term actions ensures the visibility of intentions and enhances the collective alignment and commitment. 
According to Van den Bosch \& Rotmans [13], through the deepening mechanism, actors can learn the relationships between new practices and how these can influence culture and the framework towards a sustainable direction. Thus, cultural changes, at the level of attitudes and perceptions, tend to take on practical changes, in terms of mobility behaviors and daily routines ([29], p. 49).

\subsection{Effects of Urban Living}

According to Nevens et al. ([22], p. 121), transitional urban labs can help shape a more sustainable future of the urban environment and give a sense of place to the area concerned, addressing the needs of the existing and future population. Loorbach et al. ([21], p. 253) also states that the transition approach leads to fundamental qualitative changes in society's cultures, structures, and practices, and this type of governance is focused on facilitating long-term radical change. In this regard, Von Schonfeld \& Bertolini [47] highlight, from the repertoire of public space typologies, the role of urban streets, for the functional duplicity that they can encompass, on the one hand, as a channel that provides mobility and, on the other hand, (as essential as the previous one) the potential to promote social interaction through the provision of a wide diversity of activities.

\section{Critical Debate}

The authors Rotmans et al. [19], consider that knowledge about governance for social change in a desirable and sustainable way has evolved substantially in recent decades, through Transition Management, and refer to the importance of empirical case studies to evaluate these processes and validate their effectiveness (which may still take a decade or two). However, a transition process frames its own dynamics and involves a cascade of system innovations, which characterize it as a continuous and open process. [19].

The transition approach has taken a critical stance towards incremental policies, which do not really question the unsustainable regimes, and which put at risk real political support for radical innovations ([21], p. 253). However, due to the complexity and uncertainty inherent to the issue, Transition Management cannot assume a command and control posture, but rather a management of influence towards sustainability and a Reflective Governance of a complex and adaptive system ([19], p. 8).

Shove \& Walker ([20], pp. 3-7) warn that directing change towards sustainability is a complex task that has to deal with hegemonic capitalist ideologies and practices, highlighting the following critical points/issues. For this, they begin with a set of questions:

1. Who are the critical actors in the process and with what legitimacy do they act?

In this sense, they argue that there be "managers" who should assume a privileged position, experienced and, above all, external, in parallel, to the actors that are part of the system. However, Rotmans et al. ([19], p. 11) counter that transition management cannot be managed in the classical, top-down, command and control sense. They argue that pioneers of change should be given space and be empowered (by providing knowledge and removing barriers), as well as have an ambitious long-term vision (allowing time for new and challenging ideas vis-à-vis the current regime), framed within an agenda carried out by the various actors. They also argue that this agenda should include financial incentives to make it viable, and that it should be implemented through small-scale innovative experiences.

On the other hand, Rotmans et al. ([19], p. 9) refer to the importance of researchers assuming a "helicopter view" (distancing themselves) in the analysis of the system and simultaneously an "actor view", constituting themselves as an agent of structural change, by introducing innovative concepts to accelerate transitions.

Again, Rotmans et al. ([19], p. 11) state that there is no hierarchy of actors, but that each plays a specific role in the transition (e.g., some build legitimacy among politicians, others create coalitions between parties, others link existing experiences, others are involved in bureaucratic activities, still others develop practical guidelines).

2. When and how are transition management objectives subject to critical scrutiny and by whom? 
Visions of the future may be shaped by the social systems and environments of the present, and as such, initiatives may take on an effect of neutralizing change rather than embracing disagreement.

3. Who wins and who loses with a given direction of transition?

Visions of the future should entail a democratic and equitable choice of options, but it is necessary to recognize that interim models of transition confer policy options that can only be partially inclusive (multi-stakeholder) and contingent (due to the constant and continuous dynamics inherent). In this sense, the importance of Reflective Governance that allows for feedback, monitoring, and continuous improvement in the transition process emerges.

4. What are the institutions of Transition Management and what are the mechanisms and targets of Reflective Governance?

Although there is no consensus among the various researchers of Transition Experiments, Shove \& Walker ([20], p. 6) argue that Transition Management strategies imply a radical revision of theories and orientation. However, they consider that the necessary social and environmental changes can be incorporated into current practices, with a more frequent review of objectives and with longer time horizons.

Rotmans et al. ([19], p. 12) also consider that it is essential to monitor the dynamics of transition through quantitative indicators (e.g., economic, ecological, and social), as well as through qualitative indicators of change in attitudes and behaviors. This reflective monitoring enables ongoing feedback to people and stakeholders and incorporates the cyclical concept of continuous improvement into the Transition Management process (problem perception, sustainability vision, transition pathways, and Transition Experiments can be continuously adjusted based on inherent social learning).

5. How can we respond to the rapid and powerful spread of unsustainable practices?

Alongside the Transition Management for Sustainability, there are opposing competing trends (related to the comfort provided by polluting technologies) that are generally absent from the Transition Management literature and, as such, there are as yet no sure ways to counter them. Indeed, the standardization of consumer expectations underpins practical complexities that correspond to unsustainable standards ([20], p. 7).

Rotmans et al. ([19], p. 13) point out in this regard that persistent problems cannot be solved through traditional political strategies, nor can they be self-resolved by the market, but rather they require radical innovations such as Transition Management and that the disappearance of the current regime can only be a prerequisite for the emergence of a new, more sustainable regime.

In summary, Shove \& Walker ([20], pp. 7-8) conclude that there is no clear model for managing change processes and that there are important change agents that are not always considered in reflective transition.

Rotmans et al. [19] dispute the criticism presented by Shove \& Walker [20] for ignoring the research already carried out on the social systems underlying Transition Management, as well as on the role of Reflective Governance adjusted to Sustainable Development. Such an approach places a degree of unpredictability in the processes.

On the other hand, Sengers ([12], p. 161) lists that the main theoretical criticisms of Transition Experiments related to

- Doubts whether the application of the innovation and the assessment of vulnerabilities to the exposure of pressures, of a given Real Life Laboratory, should be restricted to the initial stage or extended over time;

- Doubts whether prior to the experience a shared vision should be created;

- Doubts whether market policies or civil society should be considered as a basis, given that the issues addressed in the laboratory go beyond the strict limits of the laboratory;

- Sometimes experiences constitute isolated events that are forgotten and whose effects are lessened in time; 
- Transitional, small-scale experiments must be accompanied by tough measures and in interaction with other instruments to dismantle the current regime;

- Issues of social justice, equity, and exclusion present in the selection of the stakeholders involved will impact the negotiations and participation and their positioning in the Transition Experiment and will influence the outcome.

- The existence of controversies in the transition team may condition structural changes.

According to Nevens et al. ([22], p. 112) despite the potential effectiveness of addressing global issues at a city level, there are barriers that create inertia. Just as at the global level, at a local level, the complexity, uncertainty, and persistence of certain problems related to unsustainability are also evident, requiring the overcoming of spatial, temporal, and institutional barriers to make the transition effective. Complementing this, Loorbach et al. [21] argue for greater investment in translocal transition governance that reconciles global sustainability challenges, addressed at the level of networks of exchange and diffusion of ideas and values, with the potential to embed transformative innovations locally to support sustainability. In this sense, an innovative transformation (globally connected but locally rooted) is developed with a collective and shared transition agenda (e.g., at the level of experiences, lessons, and/or the context of capacity development and diffusion), through networked coalitions, with the aim of enhancing broader systemic change in society. This translocal perspective on transition helps create collective momentum through the creation of partnerships and through replication.

Finally, Nevens et al. ([22], p. 118-119) also list the following barriers that may condition the transition process:

1. the definition of pioneering agents

- Select pioneering agents who, in addition to innovation capabilities, incorporate communication skills and competencies. On the other hand, although TE involve multiple stakeholders, because the focus is given to the pioneering change agents, the process risks being seized by them ([31], p. 10);

- Identify and tactically re-evaluate the participation of truly genuine pioneering actors;

- Balancing the need for consensus building prolonged in time and without very tangible results while maintaining the interest and motivation of members of the arena;

- Overcome the dominance of betting and representation by consolidating a mindset of engagement and consensus building.

2. in terms of the implementation of experiments

- $\quad$ Ensuring people engage in genuine and new experiences that carry risk and uncertainty;

- Ensure funding for Transition Experiments without requiring increased effort from any partner;

- Explicitly link the experience to a broader context (relationship between the future vision, transition paths, and actions);

Assume that a Transition Experiment, due to the combination of perceptions and the degree of uncertainty implied, may not achieve the expected goal and therefore may fail, but a Transition Experiment only fails if nothing is learned from it, since social learning is one of the primary objectives.

\section{Summary and Future Pathways}

This article reinforced the importance of new forms of governance and Transition Experiments (TE) to achieve a more sustainable society, as advocated in the Paris Agreement. There are several studies that address TE in various aspects of sustainability, but with regard to Sustainable Urban Mobility (SUM), it is necessary to systematize the review of updated literature.

It was found that this transition will not be achievable with traditional planning practices that are too technocratic and stuck with respect to the physical aspect, but must incorporate a socio-cultural transition. Thus, along with the physical change, necessary for 
the consummation of the transition to SUM in cities, there is the essential socio-cultural change in this matter, which implies a change in the Governance of Mobility.

Banister highlights the importance of the responsibility of Local Governance and the respective conviction towards a coherent long-term vision to ensure community behavior change.

Despite the political commitments made and the high investment in the physical space to promote SUM, there is some inability to achieve the ambitious decarbonization targets through incremental planning methodologies. This situation reinforces TE as the most suitable tool for this purpose by focusing on learning through a reflective and innovative process and by incorporating the socio-cultural component to the physical component. Likewise, the applications of disruptive actions within TE influence the desirable systemic changes.

TE, being guided by a vision of long-term sustainability, articulated with short-term actions applied at the micro scale (Living labs) in the sphere of SUM promotion, imply a redistribution or reallocation of public spaces that are currently mostly allocated to individual transport (in Portugal more than $60 \%$ of the population commutes by car) to soft modes (especially walking).

$\mathrm{TE}$ are, therefore, long-term innovation and social learning projects, implemented in transition arenas through the constitution of a transition team, composed of agents of change that promote the empowerment of the remaining agents and that define a change scenario employed in a continuous evaluation process. The change agents stand out from the various stakeholders that make up the transition arena by their propensity for innovation and potential contribution to the paradigm shift.

This transition arena is applied at the scale of the local community through a process of social and institutional learning motivated by a direction of transition towards sustainability.

Within the scope of promoting Sustainable Urban Mobility, these learning experiences, which take place in a real-life context, imply the redistribution of public space among transport modes in an equitable way, raising community awareness for more sustainable modes.

Transition Experiments are thus opposed to traditional planning and incremental policies that condition the articulation of long-term strategy with short-term implementation of solutions for persistent problems and for the achievement of the promotion of sustainable urban mobility and the real shift towards a sustainable regime.

The Transition Experiments go beyond innovation projects due to the learning component and the socio-cultural and institutional transformation that they incorporate, through a reflexive Governance logic, as well as the effective implementation of new sustainability practices that contribute to the acceleration of the transition.

Despite the intrinsic added value, design criteria do not always assume a prevalence and adequate care in the Transition Experiments, be it on a practical level or at the level of the research that has been produced on this matter. The specificity of the collaborative design that is inherent in the concept of Transition Experiments is, in itself, a challenge for architects who lead and accompany these processes and who should, on the one hand, use design tools that contribute to the collective construction of a transition model and, on the other hand, incorporate in the project the consensus established in the continuous participation process.

The research developed in terms of Transition Experiments, despite the relevance and timeliness of the theme at a global level, given the concerns about climate change, the need to comply with the Paris Agreement and the Green Deal, has been developed mainly in the Netherlands. In Portugal, research on this subject is scarce, and its applicability to structuring cities for the Portuguese territory is non-existent. Braga has been reflecting on these matters with its European partners from established city networks (e.g., Beacon, CityMobilNet-Urbact, RegenerationMix-Urbact) and is in the process of practical implementation as a living laboratory through the application of Transition Experiments in strategic pilot areas in the city. 
On the other hand, it is considered that further exploration of the role of urban design of public spaces in TE is needed in future studies. This is a matter that still needs to be studied and that may represent a decisive contribution (in conjunction with the involvement of the population) to the aims of regime change associated with TE.

This paper contributes to the consolidation of a comprehensive vision of TE and to the specific nature of the application of this concept to the promotion of SUM. In this sense, it is believed to constitute a decisive contribution for the development of future practical work, such as those that the authors will apply to the laboratory of a resilient and sustainable urban system in the city of Braga. The continuation of these works, in turn, will allow the dissemination of the TE concept in Portugal and will contribute to the decarbonization and fulfilment of the 2050 targets in an evidence-based way.

As discussed by Rotmans et al. [19], the integration of the Transesclar perspective (simultaneously considering the macro, meso, micro, and capillary levels) [16] with the TE also presents a potential for the dissemination, which could be decisive for the regime change towards the promotion of SUM. In fact, understanding the territory as a whole, even when intervening at the micro or capillary level is fundamental to increase the potential of the application of TE and to ensure that short-term interventions have an impact in the long term.

Funding: This research was funded by Fundação para a Ciência and a Tecnologia, IP (FCT)/ Massachusetts Institute of Technology (MIT-Portugal), grant number SFRH/BD/151416/2021, in the context of the doctoral thesis of Filipa Corais, with the title "THE CITY "WALKING" TO 2050. BRAGA AS A LABORATORY FOR A RESILIENT \& SUSTAINABLE SYSTEM".

Institutional Review Board Statement: Not applicable.

Informed Consent Statement: Not applicable.

Data Availability Statement: Not applicable.

Acknowledgments: The authors would like to thank the Department responsible for the Connection to Universities and to the Mobility Department of Braga City Hall for all support provided in the action-research that is being embodied in the development of the $\mathrm{PhD}$ thesis "The city moving towards 2050. Braga as a Laboratory for a Sustainable and Resilient Urban System," (Corais, 2020) and from which the present literature review was extracted that will substantiate the future works to be applied to Braga's case study. The authors would also like to thank the reviewers of the document and the guidance team (Marta Labastida) of the aforementioned PhD thesis (Corais, 2020) for their valuable contributions.

Conflicts of Interest: The authors declare no conflict of interest. 


\section{Appendix A}

Table A1. Level of importance of the 120 publications of TE considered.

\begin{tabular}{|c|c|c|}
\hline & Author & Level of Importance \\
\hline 1 & $\begin{array}{c}\text { Avelino, F. and Wittmayer, J.M. (2016) Shifting power relations in sustainability transitions: A multi-actor perspective, } \\
\text { Journal of Environmental Policy \& Planning, 18(5), 628-649. }\end{array}$ & $* * *$ \\
\hline 2 & $\begin{array}{c}\text { Avelino, F., \& Grin, J. (2016). Beyond deconstruction: a reconstructive perspective on sustainability transition } \\
\text { governance. Environmental Innovation and Societal Transitions, 22, 15-25. }\end{array}$ & $* * *$ \\
\hline 3 & $\begin{array}{c}\text { Avelino, F., Grin, J., Jhagroe, S. and Pel, B. (2016) The politics of sustainability transitions, Journal of Environmental } \\
\text { Policy \& Planning, 18(5), 557-567. }\end{array}$ & $* * *$ \\
\hline 4 & $\begin{array}{c}\text { Avelino, F. (2011). Power and mobility in transition; empowering sustainability governance. PhD thesis. Erasmus } \\
\text { University Rotterdam. To be published. }\end{array}$ & $* * * * *$ \\
\hline 5 & $\begin{array}{c}\text { Avelino, F. and Rotmans, J. (2011). A dynamic conceptualization of power for sustainability research. Journal of } \\
\text { Cleaner Production, } 19 \text { (8), pp. 796-804. }\end{array}$ & \\
\hline 6 & $\begin{array}{l}\text { Avelino, F. (2009). Empowerment and the challenge of applying transition management to ongoing projects. Policy } \\
\text { Sciences 42, 369-390. }\end{array}$ & $* * * *$ \\
\hline 7 & $\begin{array}{c}\text { Avelino, F. and Rotmans, J. (2009). Power in Transition. An Interdisciplinary Framework to Study Power in Relation to } \\
\text { Structural Change. European Journal of Social Theory 12(4), 543-569. }\end{array}$ & $* * *$ \\
\hline 8 & $\begin{array}{c}\text { Bertolini, L. (2020). From "streets for traffic" to "streets for people": can street experiments transform urban mobility? } \\
\text { Transport Reviews, 1-20. }\end{array}$ & $* * * * *$ \\
\hline 9 & $\begin{array}{l}\text { BERTOLINI, Luca; LE Clerq, Frank; STRAATEMEIER, Thomas (2008). Urban transportation planning in transition. } \\
\text { Editorial/Transport Policy } 15 \text { (2008) 69-72. }\end{array}$ & $* * *$ \\
\hline 10 & Bettini (2015). Understanding institutional capacity for urban water transitions. & ** \\
\hline 11 & Bos et al. (2013). A design framework for creating social learning situations. & * \\
\hline 12 & $\begin{array}{l}\text { Brown et al. (2013). Actors working the institutions in sustainability transitions: The case of Melbourne's } \\
\text { stormwater management. }\end{array}$ & * \\
\hline 13 & $\begin{array}{l}\text { Brown, H.S., Vergragt, P.J., Green, K. and Berchicci, L. (2003). Learning for Sustainability Transition through Bounded } \\
\text { Socio-Technical Experiments in Personal Mobility. Technology Analysis and Strategic Management 13(3), 298-315. }\end{array}$ & * \\
\hline 14 & $\begin{array}{c}\text { Bulkeley, H., Broto, V.C., Maassen, A. (2013). Low-carbon transitions and the reconfiguration of urban infrastructure, } \\
\text { Urban Studies, 51(7), 1471-1486. }\end{array}$ & $* * *$ \\
\hline 15 & Bulkeley, H., Castan-Broto, V., Hodson, M., Marvin, S. (2011). Cities and low-carbon transitions. Routledge. & $* * *$ \\
\hline 16 & 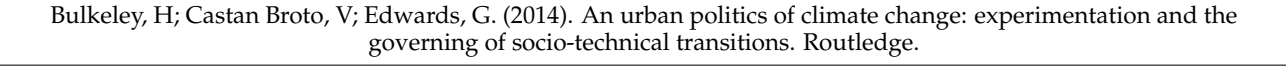 & $* * *$ \\
\hline 17 & Burton, E., Jenks, M., \& Williams, K. (Eds.). (2003). The compact city: a sustainable urban form? Routledge. & $* * *$ \\
\hline 18 & $\begin{array}{l}\text { Bush, R; Bale, C; Powell, M. et al. (2017). The role of intermediaries in low carbon transitions-empowering } \\
\text { innovations to unlock district heating in the UK. Journal of Cleaner Production, available online. }\end{array}$ & $* * *$ \\
\hline 19 & $\begin{array}{c}\text { Castán Broto, Vanesa; Westman, Linda K. (2020). Ten years after Copenhagen: Reimagining climate change } \\
\text { governance in urban areas. }\end{array}$ & $* * *$ \\
\hline 20 & $\begin{array}{l}\text { Castan Broto, V., Bulkeley, H. (2013). A survey of urban climate change experiments in } 100 \text { cities. Glob. Environ. } \\
\text { Chang. 23, 92-102. }\end{array}$ & $* * * *$ \\
\hline 21 & $\begin{array}{l}\text { Chilvers, J. and N. Longhurst. (2016). Participation in Transition(s): Reconceiving Public Engagements in Energy } \\
\text { Transitions as Co-Produced, Emergent and Diverse. Journal of Environmental Policy \& Planning 18(5), 585-607. }\end{array}$ & $* * *$ \\
\hline 22 & $\begin{array}{l}\text { Coenen, L. and Truffer, B. (2012). Places and spaces of sustainability transitions: Geographical contributions to an } \\
\text { emerging research and policy field, European Planning Studies, 20(3), 367-374. }\end{array}$ & $* * *$ \\
\hline 23 & $\begin{array}{c}\text { Coenen, L., Benneworth, P., Truffer, B. (2012). Toward a spatial perspective on sustainability transitions. Research } \\
\text { Policy, 41, 968-979. }\end{array}$ & $* * *$ \\
\hline 24 & $\begin{array}{l}\text { Dadush, U., and B. Stancil (2010). 'The World Order in 2050.' Policy Outlook, Carnegie Endowment for International } \\
\text { Peace, Washington, DC. http:/ / carnegieendowment.org/files/World_Order_in_2050.pdf (accessed on } 12 \text { June 2021) }\end{array}$ & $* * *$ \\
\hline 25 & $\begin{array}{c}\text { De Bruijne et al. (2010). Dealing with dilemmas: How can experiments contribute to a more sustainable } \\
\text { mobility system. }\end{array}$ & $* * * * *$ \\
\hline 26 & $\begin{array}{l}\text { Ehnert, F, Kern F, Borgström, S, Gorissen, L, Maschmeyer S., and Egermann, M. (2017). Urban sustainability } \\
\text { transitions in a context of multi-level governance: A comparison of four European states. Environmental Innovation } \\
\text { and SocietalTransitions. }\end{array}$ & $* * * * *$ \\
\hline 27 & European Environment Agency (2016). Sustainability Transitions: Now for the long term. Eionet Report 1/2016. & $* * *$ \\
\hline 28 & $\begin{array}{l}\text { Evans, James; Karvonen, Andrew and Raven, Rob (2016). The Experimental City. Abingdon, Oxon; New York, NY: } \\
\text { Routledge, 2016; ISBN: 978-1-138-85620-2 (hbk) ISBN: 978-1-315-71982-5 (ebk). }\end{array}$ & $* * *$ \\
\hline 29 & $\begin{array}{c}\text { Foxon, Timothy J., Peter J.G. Pearson, Stathis Arapostathis, Anna Carlsson-Hyslop, and Judith Thornton. (2013). } \\
\text { Branching Points for Transition Pathways: Assessing Responses of Actors to Challenges on Pathways to a Low Carbon } \\
\text { Future." Energy Policy } 52 \text { (January): 146-158. doi:10.1016/j.enpol.2012.04.030 }\end{array}$ & $* * *$ \\
\hline 30 & $\begin{array}{l}\text { Foxon et al. (2009). Governing long-term social-ecological change: What can the adaptive management and transition } \\
\text { management approaches learn from each other? }\end{array}$ & $* * * *$ \\
\hline
\end{tabular}


Table A1. Cont.

\begin{tabular}{|c|c|c|}
\hline & Author & Level of Importance \\
\hline 31 & $\begin{array}{l}\text { Frantzeskakia; Vandergertc; Connopc; Schipperb; Zwierzchowskad; Colliere; Lodderb (2020); Examining the policy } \\
\text { needs for implementing nature-based solutions in cities: Findings from city-wide transdisciplinary experiences in } \\
\text { Glasgow (UK), Genk (Belgium) and Poznań (Poland). }\end{array}$ & $* * *$ \\
\hline 32 & $\begin{array}{l}\text { Frantzeskaki, Niki; Castán Broto, Vanesa; Coenen, Lars; Loorbach, Derk (2017). Urban Sustainability Transitions. } \\
\text { NY-Routledge; ISBN 9781315228389. }\end{array}$ & $* * * *$ \\
\hline 33 & $\begin{array}{l}\text { Frantzeskaki, F., Thissen, W., and J. Grin (2012). 'Drifting between Transitions, The Environmental Protection } \\
\text { Transition in Greece.' 3rd International Conference of Sustainability Transitions, Copenhagen, August 26-28. }\end{array}$ & $* * *$ \\
\hline 34 & $\begin{array}{c}\text { Frantzeskaki, N., D. Loorbach, and J. Meadowcroft (2012). 'Governing Transitions to Sustainability: Transition } \\
\text { Management as a Governance Approach towards Pursuing Sustainability.' International Journal of Sustainable } \\
\text { Development 15: 19-36. }\end{array}$ & $* * *$ \\
\hline 35 & $\begin{array}{l}\text { Frantzeskaki, N., J. Koppenjan, D. Loorbach, N. Ryan, and M. Charles. (2012). 'Theoretical and Empirical } \\
\text { Contributions to an Understanding of the Governability of System Transitions to Sustainability-Lessons and } \\
\text { Next-Step Challenges.' International Journal of Sustainable Development 15: 173-186. }\end{array}$ & $* * *$ \\
\hline 36 & $\begin{array}{c}\text { Frantzeskaki et al. (2014). The role of partnerships in realising urban sustainability in Rotterdam's City Ports Area The } \\
\text { Netherlands. }\end{array}$ & $* * * *$ \\
\hline 37 & Frantzeskaki et al. (2012). Governing societal transitions to sustainability. & $* * * *$ \\
\hline 38 & $\begin{array}{c}\text { Frantzeskaki \& Loorbach (2010). Towards governing infrasystem transitions: Reinforcing lock-in or } \\
\text { facilitating change? }\end{array}$ & $* * *$ \\
\hline 39 & $\begin{array}{l}\text { Frantzeskaki, F., and H. de Haan(2009). ‘Transitions: Two Steps from Theory to Policy.' Futures 41(9): 593-606. } \\
\text { http:/ / dx.doi.org/10.1016/j.futures.2009.04.009 (accessed on } 12 \text { June 2021). }\end{array}$ & $* * *$ \\
\hline 40 & $\begin{array}{l}\text { GEELS, Frank W. (2012). A socio-technical analysis of low-carbon transitions: introducing the multi-level perspective } \\
\text { into transport studies. Journal of Transport Geography } 24 \text { (2012) 471-482. }\end{array}$ & $* * *$ \\
\hline 41 & $\begin{array}{c}\text { Geels, F. and Schot, J. (2010). The dynamics of socio-technical transitions: a sociotechnical perspective, part I in: Grin, } \\
\text { J., Rotmans, J. and Schot, J. (eds.) Transitions to Sustainable Development; New Directions in the Study of Long } \\
\text { TermTransformative Change. New York: Routledge }\end{array}$ & $* * *$ \\
\hline 42 & $\begin{array}{c}\text { Geels, F.W. (2014). Regime Resistance against Low-Carbon Transitions: Introducing Politics and Power into the } \\
\text { Multi-Level Perspective. Theory, Culture \& Society, 31, 21-40. }\end{array}$ & $* * *$ \\
\hline 43 & $\begin{array}{l}\text { Gliedt, ravis; Larson, Kelli (2018). Sustainability in transition. Routledge, ebook ISBN 9781315537139; } \\
\text { https:/ / doi.org/10.4324/9781315537139 (accessed on 12 June 2021) }\end{array}$ & $* * *$ \\
\hline 44 & $\begin{array}{l}\text { Gorissen, L., Spira, F., Meyers, E., Velkering, P., and Frantzeskaki, N., (2017), Moving towards systemic change? } \\
\text { Investigating acceleration dynamics of urban sustainability transitions in the Belgian City of Genk, Journal of } \\
\text { Cleaner Production. }\end{array}$ & $* * *$ \\
\hline 45 & $\begin{array}{c}\text { Gorris, T. and Pommer, J. (2008). Transition to sustainable mobility; theory put into practice. Transport Research Arena } \\
\text { Europe 2008, Ljubljana. }\end{array}$ & $* * *$ \\
\hline 46 & $\begin{array}{c}\text { Gorris, T. and Van den Bosch, S. (2008). Putting Transition Theory into Practice: the case of the Transumo Transition } \\
\text { Programme. NECTAR Workshop "Transition towards Sustainable Mobility: The Role of Instruments, Individuals and } \\
\text { Institutions". Rotterdam, 15-16 May } 2008 .\end{array}$ & $* * *$ \\
\hline 47 & $\begin{array}{c}\text { Gössling, S., \& Cohen, S. (2014). Why sustainable transport policies will fail: EU climate policy in the light of transport } \\
\text { taboos. Journal of Transport Geography, 39, 197-207. }\end{array}$ & $* * *$ \\
\hline 48 & $\begin{array}{c}\text { Graham, S., Marvin, S. (2001). Splintering Urbanism. Networked infrastructure, technological mobilities and the } \\
\text { urban condition. Routledge }\end{array}$ & $* * *$ \\
\hline 49 & $\begin{array}{c}\text { Grin, J., Rotmans, J., \& Schot, J. (2010). Transitions to Sustainable Development: New Directions in the Study of Long } \\
\text { Term Transformative Change (1 edition). New York: Routledge }\end{array}$ & $* * *$ \\
\hline 50 & $\begin{array}{c}\text { Hamann, R., April, K. (2013). On the role and capabilities of collaborative intermediary organisations in urban } \\
\text { sustainability transitions. Journal of Cleaner Production, Special Issue: Advancing sustainable urban transformation } \\
50,12-21 \text {. doi:10.1016/j.jclepro.2012.11.017 }\end{array}$ & $* * *$ \\
\hline 51 & $\begin{array}{c}\text { HICKMAN, Robin; HALL, Peter; BANISTER, David (2013). Planning more for sustainable mobility. Journal of } \\
\text { Transport Geography. }\end{array}$ & $* * * *$ \\
\hline 52 & $\begin{array}{l}\text { Hodson, M. and Marvin, S. (2010), Can cities shape socio-technical transitions and how would we know if they were? } \\
\text { Research Policy, 39(4), 477-485. }\end{array}$ & $* * *$ \\
\hline 53 & $\begin{array}{l}\text { Hodson, M., Marvin, S. (2012). Mediating low-carbon transitions? Forms of organization, knowledge and action. } \\
\text { European Planning Studies. 20, 421-439. }\end{array}$ & $* * *$ \\
\hline 54 & $\begin{array}{l}\text { Hodson, M., Geels, F.W., \& McMeekin, A. (2017). Reconfiguring Urban Sustainability Transitions, Analysing } \\
\text { Multiplicity. Sustainability, 9(2), } 299 .\end{array}$ & $* * *$ \\
\hline 55 & $\begin{array}{l}\text { Hoffman, J. (2013). Theorizing power in transition studies: the role of creativity in novel practices in structural change, } \\
\text { Policy Sciences, 46(3), 257-275 }\end{array}$ & $* * *$ \\
\hline 56 & $\begin{array}{l}\text { Hoffman, J., and Loeber, A. (2016) Exploring the micro-politics in transitions from a practice perspective: The case of } \\
\text { greenhouse innovation in the Netherlands, Journal of Environmental Policy \& Planning, 18(5), 692-711. }\end{array}$ & $* * *$ \\
\hline 57 & $\begin{array}{c}\text { Hoogma R, Kemp R, Schot J, Truffer B. (2002). Experimenting for SustainableTransport: The approach of Strategic } \\
\text { Niche Management. London: Spon Press. }\end{array}$ & $* * *$ \\
\hline 58 & $\begin{array}{l}\text { HOUGHTON, Kirralie; CHOI, Jaz Hee-jeong; LUGMAYR, Artur. (2011). Cities, mobility and climate change. Journal } \\
\text { of Transport Geography. }\end{array}$ & $* * * * *$ \\
\hline
\end{tabular}


Table A1. Cont.

\begin{tabular}{|c|c|c|}
\hline & Author & Level of Importance \\
\hline 59 & $\begin{array}{l}\text { Jong, M. de., Joss, S., Schraven, D., Zhan, C.,Weijnen, M. (2015). Sustainable-smart resilient- low } \\
\text { carbon-eco-knowledge cities; making sense of a multitude of concepts promoting sustainable urbanization. Journal of } \\
\text { Cleaner Production. 109, 25-38. }\end{array}$ & $* * *$ \\
\hline 60 & Kanger, L, and Schot, J. (2016). User-Made Immobilities: A Transitions Perspective. Mobilities 11 (4), 598-613 & $* * *$ \\
\hline 61 & Kemp et al. (2011). Transition management as a model for sustainable mobility. & $* * *$ \\
\hline 62 & $\begin{array}{c}\text { Kemp, René; Loorbach, D.; Rotmans, J. (2007). Transition management as a model for managing processes of } \\
\text { co-evolution towards sustainable development. }\end{array}$ & *** \\
\hline 63 & $\begin{array}{c}\text { Köhler, J., Whitmarsh, L., Nykvist, B., Schilperoord Bergman, N. and Haxeltine, A. (2009). A transition model for } \\
\text { sustainable mobility. Ecological Economics, 68, 2985-2995. }\end{array}$ & $* * *$ \\
\hline 64 & $\begin{array}{l}\text { Köhler, J., de Haan, F.J., Holtz, G., Kubeczko, K., Moallemi, E.A., Papachristos, G., Chappin E. (2018) Modelling } \\
\text { Sustainability Transitions: An assessment of approaches and challenges, Journal of Artificial Societies and Social } \\
\text { Simulation, 21(1), } 8 \text { doi: } 10.18564 / \text { jasss.3629. }\end{array}$ & $* * *$ \\
\hline 65 & $\begin{array}{l}\text { Köhler J., Turnheim B., Hodson M. (in review) Low Carbon Transitions Pathways in Mobility: applying the MLP in a } \\
\text { combined case study and simulation bridging analysis, Technological Forecasting and Social Change (in review). }\end{array}$ & $* * *$ \\
\hline 66 & Liedtke et al. (2015). User-integrated innovation in Sustainable LivingLabs. & $* * *$ \\
\hline 67 & Loorbach, Wittmayer, Avelino, von Wirth, Frantzeskaki (2020). Transformative innovation and translocal diffusion. & $* * *$ \\
\hline 68 & $\begin{array}{c}\text { Loorbach, Derk; Frantzeskaki, Niki; Huffenreuter, Roebin Lijnis (2015). Transition Management Taking Stock from } \\
\text { Governance Experimentation. DOI: [10.9774/GLEAF.4700.2015.ju.00008] }\end{array}$ & $* * *$ \\
\hline 69 & $\begin{array}{c}\text { Loorbach, D., (2014). To Transition! Governance Panarchy in the New Transformation. Rotterdam: DRIFT-Erasmus } \\
\text { University Rotterdam. }\end{array}$ & $* * *$ \\
\hline 70 & $\begin{array}{c}\text { Loorbach, D.A. and Huffenreuter, L. (2013). Exploring the economic crisis from a transition management perspective, } \\
\text { Environmental Innovation and Societal Transitions, 6, 35-46. }\end{array}$ & $* * *$ \\
\hline 71 & $\begin{array}{l}\text { Loorbach; Wijsman (2013). Business transition management: exploring a new role for business in } \\
\text { sustainability transitions. }\end{array}$ & $* * * *$ \\
\hline 72 & $\begin{array}{l}\text { Loorbach, D., N. Frantzeskaki, and W. Thissen. (2011). A Transition Research Perspective on Governance for } \\
\text { Sustainability.' In European Research on Sustainable Development-1: Transformative Science Approaches for } \\
\text { Sustainability, C.C. Jaeger, David J. Tàbara, and J. Jaeger, (Eds.), 73-89. Berlin: Springer. }\end{array}$ & $* * *$ \\
\hline 73 & Loorbach; Frantzeskaki; Thissen (2010). Introduction to the special section: Infrastructures and transitions. & $* * * *$ \\
\hline 74 & $\begin{array}{c}\text { Loorbach, D. (2010) Transition management for sustainable development: A prescriptive, complexity-based } \\
\text { governance framework, Governance, 23(1)161-183. }\end{array}$ & $* * *$ \\
\hline 75 & Loorbach; Rotmans (2010). The practice of transition management: Examples and lessons from four distinct cases. & $* * * *$ \\
\hline 76 & $\begin{array}{l}\text { Loorbach, D. (2007). Transition Management New mode of governance for sustainable development. } \\
\text { University of Roterdam. }\end{array}$ & $* * * * *$ \\
\hline 77 & $\begin{array}{l}\text { Loorbach D, Rotmans J. (2006). Managing transitions for sustainable development. In Understanding Industrial } \\
\text { Transformation. Views from Different Disciplines, Olsthoorn X, Wieczorek AJ (eds). Springer: Dordrecht; 187-206. }\end{array}$ & $* * * *$ \\
\hline 78 & $\begin{array}{l}\text { Luederitz, C; Schapke, N; Wiek, A; et al. (2017). Learning through evaluation-A tentative evaluative scheme for } \\
\text { sustainability transition experiments. Journal of Cleaner Production, available online }\end{array}$ & *** \\
\hline 79 & $\begin{array}{l}\text { Luque-Ayala, Andrés; Marvin, Simon and Bulkeley, Harriet (2018). Rethinking urban transitions: politics in the low } \\
\text { carbon city. Oxon; New York, NY: Routledge; ISBN } 9781138057357 \text { (hardback: alk. paper) I ISBN } 9781138057401 \text { (pbk.: } \\
\text { alk. paper) I ISBN } 9781315164779 \text { (ebook) }\end{array}$ & $* * *$ \\
\hline 80 & $\begin{array}{c}\text { Markard, J. (2017). Sustainability Transitions: Exploring the emerging research field and its contribution to } \\
\text { management studies. 33rd EGOS Colloquium, Copenhagen }\end{array}$ & $* * *$ \\
\hline 81 & McAlpine et al. (2015). Transformational change_creating a safe operating space for humanity. & $* * *$ \\
\hline 82 & $\begin{array}{l}\text { Mullen C and Marsden G (2016) Mobility justice in low carbon energy transitions, Energy Research and Social Science } \\
18,109-117 .\end{array}$ & $* * *$ \\
\hline 83 & $\begin{array}{c}\text { Nevens; Frantzeskaki; Gorissen; Loorbach (2013). Urban Transition Labs: co-creating transformative action for } \\
\text { sustainable cities. }\end{array}$ & $* * * * *$ \\
\hline 84 & $\begin{array}{c}\text { Newton; Frantzeskaki (s.d.). Creating a National Urban Research and Development Platform for Advancing Urban } \\
\text { Experimentation. }\end{array}$ & $* * *$ \\
\hline 85 & $\begin{array}{l}\text { Nicolini, D. (2017) Is small the only beautiful? Making sense of 'large phenomena' from a practice-based perspective } \\
\text { in A. Hui, T. Schatzki, and E. Shove (eds.) The nexus of practice: connections, constellations and practitioners. } \\
\text { London: Routledge }\end{array}$ & $* * *$ \\
\hline 86 & Pereira et al. (2015). Organising a Safe Space for Navigating Social-Ecological Transformations to Sustainability. & $* * * *$ \\
\hline 87 & $\begin{array}{c}\text { Porter et al. (2015). Transition experiments in Amsterdam-Conceptual and empirical analysis of two transition } \\
\text { experiments in the WATERgraafsmeer program. }\end{array}$ & $* * * * *$ \\
\hline 88 & $\begin{array}{l}\text { ROORDA, Chris; WITTMAYER, Julia; HENNEMAN, Pepik; STEENBERGEN, Frank van; FRANTZESKAKI, Niki; } \\
\text { LOOBACH, Derk (2014). Management in the urban context. Transition management in the urban context: guidance } \\
\text { manual. DRIFT, Erasmus University Rotterdam. }\end{array}$ & $* * * * *$ \\
\hline 89 & $\begin{array}{l}\text { Rotmans, J., and D. Loorbach. 2009. 'Complexity and Transition Management.' Journal of Industrial Ecology } 13 \text { (2): } \\
\text { 184-96. }\end{array}$ & $* * *$ \\
\hline
\end{tabular}


Table A1. Cont.

\begin{tabular}{|c|c|c|}
\hline & Author & Level of Importance \\
\hline 90 & $\begin{array}{l}\text { Rotmans, J., Loorbach, D. and Kemp, R. (2007). Transition management: Its origin, evolution and critique. Paper } \\
\text { presented at the Workshop on “Politics and governance in sustainable so-cio-technical transitions”, 19-21 September } \\
\text { 2007, Schloss Blankensee, Berlin, Germany. }\end{array}$ & $* * * *$ \\
\hline 91 & $\begin{array}{c}\text { Rotmans, J. Kemp, R. and Van Asselt, M. (2001). More evolution than revolution: Transition management in public } \\
\text { policy. Foresight 3(1), 15-31. }\end{array}$ & $* * *$ \\
\hline 92 & $\begin{array}{c}\text { SCHUSSEL, Jéssica Cavalgante (2019). EXPERIMENTING IN PALERMO:The pedestrianisation of its historical centre. } \\
\text { FEUP, Porto. }\end{array}$ & $* * * * *$ \\
\hline 93 & $\begin{array}{l}\text { SENGERS, Frans; WIECZOREK, Anna J.; RAVEN, Rob (2019). Experimenting for sustainability transitions: A } \\
\text { systematic literature review. Technological Forecasting \& Social Change } 145 \text { (2016) 153-164. }\end{array}$ & $* * * * *$ \\
\hline 94 & $\begin{array}{c}\text { Sengers, F., Raven, R.P. (2014). Metering motorbike mobility: informal transport in transition? Technology Analysis } \\
\text { and Strategic Management 26(4), 453-468. }\end{array}$ & $* * *$ \\
\hline 95 & $\begin{array}{c}\text { SEYFANG, Gill; SMITH, Adrian (2007). Grassroots Innovations for Sustainable Development: Towards a New } \\
\text { Research and Policy Agenda. Environmental Politics. }\end{array}$ & * \\
\hline 96 & $\begin{array}{l}\text { Sheller (2015) Racialized Mobility Transitions in Philadelphia: Connecting Urban Sustainability and Transport Justice. } \\
\text { City and Society, 27: 70-91. doi:10.1111/ciso.12049 }\end{array}$ & $* * *$ \\
\hline 97 & $\begin{array}{l}\text { Shove, E., \& Walker, G. (2007). CAUTION! Transitions ahead: politics, practice, and sustainable transition } \\
\text { management. Environment and planning A, 39(4), 763-770. }\end{array}$ & $* * * *$ \\
\hline 98 & $\begin{array}{l}\text { Shove, E. (2010. Beyond ABC: climate change policy and theories of social change, Environment and Planning A, 42, } \\
\qquad 1273-1285 .\end{array}$ & $* * *$ \\
\hline 99 & $\begin{array}{c}\text { Shove, E. (2012) The shadowy side of innovation: unmaking and sustainability, Technology Analysis \& Strategic } \\
\text { Management, } 24 \text { (4), 363-375 }\end{array}$ & $* * *$ \\
\hline 100 & $\begin{array}{l}\text { Shove, E. and Walker, G. (2008) Transition Management and the Politics of Shape Shiftin', Environment and Planning } \\
\text { A, 40, 1012-1014. }\end{array}$ & $* * *$ \\
\hline 101 & Shove, E., M. Pantzar and M. Watson (2012), The Dynamics of Social Practice, London: Sage. & $* * *$ \\
\hline 102 & $\begin{array}{l}\text { Shove, Elizabeth, Matthew Watson, Martin Hand, and Jack Ingram. (2007). The Design of Everyday Life. Oxford: Berg } \\
\text { Publishers. }\end{array}$ & $* * *$ \\
\hline 103 & $\begin{array}{c}\text { SMITH, Adrian; STIRLING, Andy; BERKHOUT, Frans (2005). The governance of sustainable socio-technical } \\
\text { transitions. Research Policy } 34 \text { (2005) 1491-1510; 0048-7333/\$-see front matter. Elsevier B.V. } \\
\text { doi:10.1016/j.respol.2005.07.005. }\end{array}$ & $* * * *$ \\
\hline 104 & $\begin{array}{l}\text { SONG, Yena; PRESTON, John; OGILVIE, David (2016). New walking and cycling infrastructure and modal shift in the } \\
\text { UK: A quasi-experimental panel study. Y. Song et al./Transportation Research Part A } 95 \text { (2017) 320-333. } \\
\text { http:/ / dx.doi.org/10.1016/j.tra.2016.11.017 (accessed on 12 June 2021). }\end{array}$ & $* * * * *$ \\
\hline 105 & $\begin{array}{l}\text { Marios Stanitsas, Konstantinos Kirytopoulos, Elise Vareilles (2018). Facilitating sustainability transition through } \\
\text { serious games: A systematic literature review, Journal of Cleaner Production, Volume 208, 2019, Pages 924-936, ISSN } \\
\text { 0959-6526, https:// doi.org/10.1016/j.jclepro.2018.10.157 (accessed on 12 June 2021). }\end{array}$ & $* * * *$ \\
\hline 106 & $\begin{array}{l}\text { Stirling, A. (2008). “Opening Up" and “Closing Down”: Power, Participation, and Pluralism in the Social Appraisal of } \\
\text { Technology. Science Technology Human Values, 33(2), 262-294 }\end{array}$ & *** \\
\hline 107 & $\begin{array}{l}\text { STRN (2017). A research agenda for the Sustainability Transitions Research Network. Working group: Jonathan } \\
\text { Köhler, Frank Geels, Florian Kern, Elsie Onsongo, Anna Wieczorek. }\end{array}$ & $* * * *$ \\
\hline 108 & STRN (2010). A mission statement and research agenda for the Sustainability Transitions Research Network. & $* * * * *$ \\
\hline 109 & $\begin{array}{c}\text { Talen, E., \& Ellis, C. (2002). Beyond relativism: Reclaiming the search for good city form. Journal of Planning } \\
\text { Education and Research, 22(1), 36-49. }\end{array}$ & $* * *$ \\
\hline 110 & Tukker \& Butter (2007). Governance of sustainable transitions: about the 4(0) ways to change the world. & $* * * *$ \\
\hline 111 & $\begin{array}{l}\text { Van de Meene, S., Bettini, Y., Head, B.W. (2020) Transitioning toward sustainable cities-challenges of collaboration and } \\
\text { integration. Sustainability (Switzerland), 2020, 12(11), } 4509 .\end{array}$ & ** \\
\hline 112 & $\begin{array}{l}\text { VAN DEN BOSCH, Suzanne; ROTMANS, Jan (2008). Deepening, Broadening and Scaling up: a Framework for } \\
\text { Steering Transition Experiments. }\end{array}$ & $* * * * *$ \\
\hline 113 & VAN DEN BOSCH, Suzanne (2010). Transition Experiments: Exploring Societal Changes Towards Sustainability. & $* * * * *$ \\
\hline 114 & Van Herk et al. (2015). Understanding the transition to integrated flood risk management in the Netherlands. & * \\
\hline 115 & $\begin{array}{l}\text { VINCI, Ignazio; DIO, Salvatore di (2014). Designing Mobility in a City in Transition Challenges from the case of } \\
\text { Palermo. TeMA INPUT 2014-Journal of Land use, Mobility and Environment; Smart city. Planning for energy, } \\
\text { transportation and sustainability of the urban system. Print ISSN 1970-9889, e- ISSN 1970-9870; University of Naples } \\
\text { Federico II. }\end{array}$ & $* * * *$ \\
\hline 116 & $\begin{array}{l}\text { Voß, J.P. (2014). Performative policy studies: realizing "transition management". Innovation: The European Journal of } \\
\text { Social Science Research, 27(4), 317-343. }\end{array}$ & $* * *$ \\
\hline 117 & $\begin{array}{l}\text { Voß \& Bornemann (2011). The politics of reflexive governance: Challenges for designing adaptive management and } \\
\text { transition management. }\end{array}$ & $* * * *$ \\
\hline 118 & $\begin{array}{l}\text { Voß, J-P., Smith, A., Grin, J. (2009). Designing long-term policy: Rethinking transition management, Policy Sciences, } \\
\text { 42(4): 275-302. }\end{array}$ & $* * *$ \\
\hline 119 & $\begin{array}{c}\text { Voss, J.P., Bauknecht, D., \& Kemp, R. (Eds.). (2006). Reflexive governance for sustainable development. Edward } \\
\text { Elgar Publishing }\end{array}$ & $* * *$ \\
\hline 120 & Wittmayer et al. (2014). Making sense of sustainability transitions locally. & $* * * * *$ \\
\hline
\end{tabular}




\section{References}

1. Avelino, F.; Rotmans, J. Power in transition: An interdisciplinary framework to study power in relation to structural change. Eur. J. Soc. Theory 2009, 12, 543-569. [CrossRef]

2. Bertolini, L.; Clercq, F.L.; Straatemeier, T. Urban transportation planning in transition. Transp. Policy 2008, 15, 69-72. [CrossRef]

3. Bertolini, L. From 'streets for traffic' to 'streets for people': Can street experiments transform urban mobility? Transp. Rev. 2020, 40, 734-753. [CrossRef]

4. De Bruijne, M.; van de Riet, O.; de Haan, A.; Koppenjan, J. Dealing with dilemma's: How can experiments contribute to a more sustainable mobility system? Eur. J. Transp. Infrastruct. Res. 2010, 10, 274-289. [CrossRef]

5. Geels, F.W. A socio-technical analysis of low-carbon transitions: Introducing the multi-level perspective into transport studies. J. Transp. Geogr. 2012, 24, 471-482. [CrossRef]

6. Gössling, S.; Cohen, S. Why sustainable transport policies will fail: EU climate policy in the light of transport taboos. J. Transp. Geogr. 2014, 39, 197-207. [CrossRef]

7. Kemp, R.; Loorbach, D.; Rotmans, J. Transition management as a model for managing processes of co-evolution towards sustainable development. Int. J. Sustain. Dev. World Ecol. 2007, 14, 78-91. [CrossRef]

8. Kemp, R.; Avelino, F.; Bressers, N. Transition management as a model for sustainable mobility. Eur. Transp. Trasp. Eur. 2011, 25-46.

9. Liedtke, C.; Baedeker, C.; Hasselkuß, M.; Rohn, H.; Grinewitschus, V. User-integrated innovation in Sustainable LivingLabs: An experimental infrastructure for researching and developing sustainable product service systems. J. Clean. Prod. 2016, 97, 106-116. [CrossRef]

10. Loorbach, D. Transition Management. New Mode of Governance for Sustainable Development. Ph.D. Thesis, University of Rotterdam, Rotterdam, The Netherlands, 2007.

11. Schussel, J.C. Experimenting in Palermo: The Pedestrianisation of Its Historical Centre. Master's Thesis, Spatial Planning and Urban Project. Faculty of Engineering and Faculty of Architecture of the University of Oporto, Porto, Portugal, 2019.

12. Sengers, F.; Wieczorek, A.J.; Raven, R. Experimenting for sustainability transitions: A systematic literature review. Technol. Forecast. Soc. Chang. 2019, 145, 153-164. [CrossRef]

13. Van den Bosch, S.; Rotmans, J. Deepening, Broadening and Scaling Up. A Framework for Steering Transition Experiments. 2008 Available online: https:/ / repub.eur.nl $\backslash \mathrm{T} 1 \backslash$ guilsinglrightpub $\backslash \mathrm{T} 1 \backslash$ guilsinglrightKCT_transitieboekje_02 (accessed on 12 June 2021).

14. Vinci, I.; Di Dio, S. Designing Mobility in a City in Transition. Challenges from the Case of Palermo. TeMA-J. Land Use Mobil. Environ. Available online: https:/ / doaj.org/article/b3fe56b2197f4b92ae5c7a05f2a0acff (accessed on 12 June 2021).

15. Do Território, D.G. Programa Nacional da Política de Ordenamento do Território-Alteração Diagnóstico. 2019; p. 225. Available online: https:/ / pnpot.dgterritorio.gov.pt/sites/default/files/SQ_Vconc_PNPOT_0.pdf (accessed on 12 June 2021).

16. Corais, F. A Cidade a "Caminhar" Para 2050. Braga Como Laboratório Para um Sistema Urbano Resiliente e Sustentável (Projeto Tese); Universidade do Minho: Braga, Portugal, 2021.

17. Banister, D. The sustainable mobility paradigm. Transp. Policy 2008, 15, 73-80. [CrossRef]

18. Banister, D. Cities, mobility and climate change. J. Transp. Geogr. 2011, 19, 1538-1546. [CrossRef]

19. Rotmans, J.; Loorbach, D.; Kemp, R. Transition Management: Its Origin, Evolution and Critique. 2007. Available online: https:/ / repub.eur.nl/pub/37240/Metis_125563.pdf (accessed on 12 June 2021).

20. Shove, E.; Walker, G. CAUTION! Transitions ahead: Politics, practice, and sustainable transition management. Environ. Plan. A 2007, 39, 763-770. [CrossRef]

21. Loorbach, D.; Wittmayer, J.; Avelino, F.; von Wirth, T.; Frantzeskaki, N. Transformative innovation and translocal diffusion. Environ. Innov. Soc. Transit. 2020, 35, 251-260. [CrossRef]

22. Nevens, F.; Frantzeskaki, N.; Gorissen, L.; Loorbach, D. Urban Transition Labs: Co-creating transformative action for sustainable cities. J. Clean. Prod. 2013, 50,111-122. [CrossRef]

23. Avelino, F. Power in Transition. Empowering Discourses on Sustainability Transitions. Ph.D. Thesis, Erasmus Universiteit Rotterdam, Rotterdam, The Netherlands, 2011.

24. Geels, F.W.; Hekkert, M.P.; Jacobsson, S. The dynamics of sustainable innovation journeys. Technol. Anal. Strateg. Manag. 2008, 20, 521-536. [CrossRef]

25. Köhler, J.; Geels, F.W.; Kern, F.; Onsongo, E.; Wieczorek, A.; Alkemaade, F.; Avelino, F.; Bergek, A.; Boons, F.; Bulkeley, H.; et al. STRN Research Agenda-2017. 2017, pp. 1-70. Available online: https://pure.tue.nl/ws/files/101288346/STRN_Research_ Agenda_2017.pdf (accessed on 12 June 2021).

26. Roorda, D.; Wittmayer, C.; Henneman, J.; Steenbergen, P.; van Frantzeskaki, F.; Loobach, N. Transition Management in the Urban Context (Guidance Manual); Dutch Research Institute for Transitions, Erasmus University Rotterdam: Rotterdam, The Netherlands, 2014.

27. STRN. A Mission Statement and Research Agenda for the Sustainability Transitions Research Network. Network, No. August 2010. pp. 1-27. Available online: http://www.transitionsnetwork.org/files/STRN_research_agenda_20_August_2010\%282\%29.pdf (accessed on 5 June 2019).

28. Van den Bosch, S. Transition Experiments. Ph.D. Thesis, Erasmus University Rotterdam, Rotterdam, The Netherlands, 2010.

29. Loorbach, R.L.; Frantzeskaki, D.; Huffenreuter, N. Transition management. Taking stock from Governance Experimentation. J. Corp. Citizsh. 2015, 58, 48-66. [CrossRef] 
30. Avelino, F. Empowerment and the challenge of applying transition management to ongoing projects. Policy Sci. 2009, 42, 369-390. [CrossRef]

31. Foxon, T.J.; Reed, M.S.; Stringer, L.C. Governing long-term social-ecological change: What can the adaptive management and transition management approaches learn from each other? Environ. Policy Gov. 2009, 19, 3-20. [CrossRef]

32. Loorbach, D.; Rotmans, J. Managing Transitions for Sustainable Development. In Understanding Industrial Transformation; Springer: Dordrecht, The Netherlands, 2006. [CrossRef]

33. Frantzeskaki, N.; Wittmayer, J.; Loorbach, D. The role of partnerships in "realising" urban sustainability in Rotterdam's City Ports Area, the Netherlands. J. Clean. Prod. 2014, 65, 406-417. [CrossRef]

34. Rip, A.; Kempt, R. Technological Change. In Human Choice and Climate Change; Rayner, S., Malone, E., Eds.; Battelle: Columbus, OH, USA, 1998; Volume 2, pp. 327-399.

35. Geels, F.; Kemp, R. Transities Vanuit Sociotechnisch Perspectief. Report for the Dutch Ministry of Environment. Available online: https:/ / research.utwente.nl/en/publications/transities-vanuit-sociotechnisch-perspectief (accessed on 12 June 2021).

36. Smith, A.; Stirling, A.; Berkhout, F. The governance of sustainable socio-technical transitions. Res. Policy 2005, 34, 1491-1510. [CrossRef]

37. Cervero, R.; Kockelman, K. Travel Demand and the 3Ds: Density, Diversity and Design. Pergamon 1997, 2, 199-219. [CrossRef]

38. Ewing, R.; Handy, S. Measuring the unmeasurable: Urban design qualities related to walkability. J. Urban Des. 2009, 14, 65-84. [CrossRef]

39. Ewing, R.; Cervero, R. Travel and the built environment: A synthesis [Hard-copy only]. Transp. Res. Rec. 2001, 1780, 87-114. [CrossRef]

40. Schwartz, E.E. Beyond LEED for Neighborhood Development: A contextual analysis of Urban Design and Sustainability. Master's Thesis, University of North Carolina at Chapel Hill, Chapel Hill, NC, USA, May 2008; p. 141.

41. Ewing, R.; Handy, S.; Brownson, R.C.; Clemente, O.; Winston, E. Identifying and Measuring Urban Design Qualities Related to Walkability. J. Phys. Act. Health 2006, 3, s223-s240. Available online: http://forum.activelivingresearch.com/sites/default/files/ JPAH_15_Ewing.pdf (accessed on 12 June 2021). [CrossRef]

42. Ewing, R.; Cervero, R. Travel and the built environment. J. Am. Plan. Assoc. 2010, 76, 265-294. [CrossRef]

43. Cervero, R.; Sarmiento, O.L.; Jacoby, E.; Gomez, L.F.; Neiman, A. Influences of built environments on walking and cycling: Lessons from Bogotá. Int. J. Sustain. Transp. 2009, 3, 203-226. [CrossRef]

44. Binder, R.B.; Tobey, M.B.; Jittrapirom, P.; Steidl, P.J.; Yamagata, Y.; Yang, P.P.J. Projeto de Sistemas Urbanos. In Creating Sustainable Smart Cities in the Internet of Things Era, 1st ed.; Yang, Y.Y.P., Ed.; Elsevier: Amsterdam, The Netherlands, 2020 ; pp. 125-162.

45. Sola Morales, I. Presente y Futuros. La Arquitectura en las Ciudades; Centre de Cultura Contemporània: Barcelona, Spain, 1996; pp. 10-23.

46. de Solà-Morales, M. De Cosas Urbanas; Editorial Gustavo Gili: Barcelona, Spain, 2008.

47. von Schönfeld, K.C.; Bertolini, L. Urban streets: Epitomes of planning challenges and opportunities at the interface of public space and mobility. Cities 2017, 68, 48-55. [CrossRef]

48. Porter, N.; Claassen, M.; Timmermans, J. Transition experiments in Amsterdam: Conceptual and empirical analysis of two transition experiments in the WATERgraafsmeer program. Technol. Forecast. Soc. Chang. 2015, 90, 525-537. [CrossRef]

49. Grin, J.; Rotmans, J.; Schot, J. Transitions to Sustainable Development. New Directions in the Study of Long Term Transformative Change; Francis, T., Ed.; Routledge: Oxfordshire, UK, 2010.

50. Rotmans, J.; Kemp, R.; van Asselt, M.; Geels, F.; Verbong, G.; Molendijk, K. De casus van een emissiearme energievoorziening. Int. Cent. Integr. Stud. 2000. Available online: https://kemp.unu-merit.nl/pdf/transitie.pdf (accessed on 12 June 2021). 